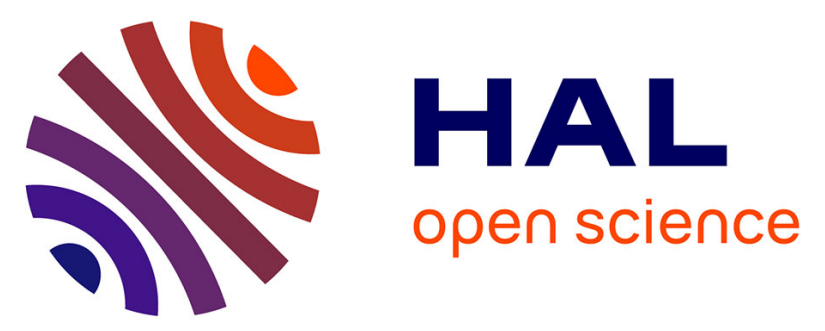

\title{
West African monsoon dynamics and precipitation: the competition between global SST warming and CO2 increase in CMIP5 idealized simulations
}

Marco Gaetani, Cyrille Flamant, Sophie Bastin, Serge Janicot, Christophe Lavaysse, Frédéric Hourdin, Pascale Braconnot, Sandrine Bony

\section{To cite this version:}

Marco Gaetani, Cyrille Flamant, Sophie Bastin, Serge Janicot, Christophe Lavaysse, et al.. West African monsoon dynamics and precipitation: the competition between global SST warming and CO2 increase in CMIP5 idealized simulations. Climate Dynamics, 2017, 48 (3), pp.1353-1373. 10.1007/s00382-016-3146-z . insu-01309682

\section{HAL Id: insu-01309682 https://hal-insu.archives-ouvertes.fr/insu-01309682}

Submitted on 4 May 2016

HAL is a multi-disciplinary open access archive for the deposit and dissemination of scientific research documents, whether they are published or not. The documents may come from teaching and research institutions in France or abroad, or from public or private research centers.
L'archive ouverte pluridisciplinaire HAL, est destinée au dépôt et à la diffusion de documents scientifiques de niveau recherche, publiés ou non, émanant des établissements d'enseignement et de recherche français ou étrangers, des laboratoires publics ou privés. 
1 West African Monsoon dynamics and precipitation: the competition between global

2 SST warming and CO2 increase in CMIP5 idealized simulations

3

4 Marco Gaetani (1,2,*), Cyrille Flamant (1), Sophie Bastin (1), Serge Janicot (3), Christophe

5 Lavaysse (4), Frederic Hourdin (2), Pascale Braconnot (5), Sandrine Bony (2)

6

7 (1) Laboratoire Atmosphères, Milieux, Observations Spatiales, LATMOS-IPSL, UMR 8190,

8 Sorbonne Universités (CNRS, UPMC), UVSQ, Paris, France

9 (2) Laboratoire de Météorologie Dynamique, LMD-IPSL, UMR 8539, Sorbonne Universités

10 (CNRS, UPMC), Ecole Normale Supérieur, Ecole Polytechnique, Paris, France

11 (3) Laboratoire d'Océanographie et du Climat: Expérimentation et Approches Numériques,

12 LOCEAN-IPSL, UMR 7159, Sorbonne Universités (CNRS, UPMC, IRD, MNHM), Paris,

13 France

14 (4) European Commission Joint Research Centre, Institute for Environment and

15 Sustainability, Ispra, Italy

16 (5) Laboratoire des Sciences du Climat et de l'Environnement, LSCE-IPSL, UMR 8212,

17 CNRS, CEA, UVSQ, Gif-sur-Yvette, France

18

$19 *$ Correspondence: marco.gaetani@latmos.ipsl.fr 


\section{Abstract}

22

23

Climate variability associated with the West African monsoon (WAM) has important environmental and socio-economic impacts in the region. However, state-of-the-art climate models still struggle in producing reliable climate predictions. An important cause of this low predictive skill is the sensitivity of climate models to different forcings. In this study, the mechanisms linking the WAM dynamics to the $\mathrm{CO} 2$ forcing are investigated, by comparing the effect of the $\mathrm{CO} 2$ direct radiative effect with its indirect effect mediated by the global sea surface warming. The July-to-September WAM variability is studied in climate simulations extracted from the Coupled Model Intercomparison Project Phase 5 (CMIP5) archive, driven by prescribed sea surface temperature (SST). The individual roles of global SST warming and $\mathrm{CO} 2$ atmospheric concentration increase are investigated through idealized experiments simulating a $4 \mathrm{~K}$ warmer SST and a quadrupled $\mathrm{CO} 2$ concentration, respectively. Results show opposite and competing responses in the WAM dynamics and precipitation. A dry response (-0.6 mm/day) to the SST warming is simulated in the Sahel, with dryer conditions over western Sahel (-0.8 mm/day). Conversely, the $\mathrm{CO} 2$ increase produces wet conditions $(+0.5 \mathrm{~mm} /$ day $)$ in the Sahel, with the strongest response over central-eastern Sahel $(+0.7$ $\mathrm{mm} / \mathrm{day}$ ). The associated responses in the atmospheric dynamics are also analysed, showing that the SST warming affects the Sahelian precipitation through modifications in the global tropical atmospheric dynamics, reducing the importance of the regional drivers, while the $\mathrm{CO} 2$ increase reinforces the coupling between precipitation and regional dynamics. A general agreement in model responses demonstrates the robustness of the identified mechanisms linking the WAM dynamics to the $\mathrm{CO} 2$ direct and indirect forcing, and indicates that these primary mechanisms are captured by climate models. Results also suggest that the spread in future projections may be caused by unbalanced model responses to the $\mathrm{CO} 2$ direct and indirect forcing. 


\section{Introduction}

West Africa is affected by large climate variability at different timescales, from interannual to multidecadal, with consequent strong environmental and socio-economic impacts, especially in the Sahelian countries, where the economy is mainly sustained by rainfed agriculture [Kandji et al., 2006]. The annual precipitation in the Sahel is limited to the boreal summer season, from July to September (JAS), and it is strongly linked to the West African monsoon (WAM) dynamics [Nicholson, 2013]. After a wet period during the 50s-60s, Sahel has undergone a severe (large scale and long-lasting) drought in the 70s-80s, and a partial recovery of precipitation has been detected at the turn of the 21 st century [Trenberth et al., 2007; Panthou et al., 2014].

WAM precipitation variability at time scales from interannual to multidecadal is mainly driven by global ocean SST anomalies [Giannini et al., 2003]. At the interannual time scale, the Tropical Atlantic SST variability modulates the monsoonal circulation through the meridional land-sea thermal gradient, affecting the meridional displacement of the precipitation belt [Losada et al., 2010], while the Mediterranean SST variability influences the moisture transport across Sahara and the associated convergence over Sahel [Fontaine et al., 2010; Gaetani et al., 2010]. Moreover, SST variability in the tropical Pacific may induce stationary Kelvin and Rossby waves propagating along the Equator and interacting over the Sahel [Rowell, 2001]. The interannual regional and remote SST connections are not stationary and are modulated by decadal and multidecadal SST anomalies [Fontaine et al., 2011]. The global ocean signals which dominate the low frequency precipitation variability in the Sahel are: the tropical SST warming, the Atlantic Multidecadal Variability (AMV), and the Interdecadal Pacific Oscillation (IPO). The tropical warming, associated to global warming and IPO positive phases, favours dry conditions in the Sahel, through the inhibition of the tropical convection [Bader and Latif, 2003; Lu and Delworth, 2005; Villamayor and Mohino, 2015]. On the other hand, positive phases of AMV, by displacing northward the intertropical convergence zone (ITCZ), favour precipitation in the Sahel [Zhang and Delworth, 2006; Ting et al., 2009; Mohino et al., 2011]. A broad and up-to-date review of the literature on the SST influence on the climate variability in West Africa is reported by [Rodríguez-Fonseca et al., 2015]. 
The WAM variability is modulated also by atmospheric circulation patterns at the regional scale, and a key driver is the thermal depression associated with the surface heating over West Africa in boreal summer. Lavaysse et al. [2009] described the seasonal evolution of this thermal low, identifying the Saharan heat low (SHL) as the area of maximum expansion of the lower troposphere, which in summer is located over Sahara, west of $10^{\circ} \mathrm{E}$. The SHL onset is closely linked to the WAM onset in late June [Lavaysse et al., 2009], and the monsoonal precipitation evolution from the onset to its mature stage is closely related to the SHL behaviour [Xue et al., 2010], with strong SHL phases associated to atmospheric circulation patterns favourable to wet conditions over central Sahel, and dry anomalies over Senegal [Lavaysse et al., 2010b]. The SHL is sensitive to regional forcings, such as synoptic systems travelling across the Sahel [Lavaysse et al., 2010a], dust emission from Sahara and Sahel [Lavaysse et al., 2011], and local water-vapour-temperature feedback [Evan et al., 2015]. On the other hand, the SHL variability is modulated by mid-latitude circulation synoptic disturbances [Chauvin et al., 2010], and northerly advections of cold air and moisture from the Mediterranean region [Vizy and Cook, 2009; Gaetani et al., 2010].

In the last 15 years, a big effort has been made in the framework of the Coupled Model Intercomparison Project Phase 3 and 5 (CMIP3 [Meehl et al., 2007] and CMIP5 [Taylor et $a l ., 2012]$, respectively) to model climate variability in West Africa, with promising but still unsatisfying results. Specifically, state-of-the-art coupled climate models show poor ability in correctly capturing the observed WAM precipitation variability, in terms of amplitude, phases and trends [Biasutti, 2013], mainly because of models' low skill in reproducing the observed SST teleconnections [Rowell, 2013]. Furthermore, in both CMIP3 and CMIP5 simulations, sizable uncertainties affect future projections, with a large spread among the outputs [Biasutti, 2013]. Most of the models predict wet conditions in the 21 st century in the Sahel, which are explained through the direct effect of the increase in green-house gases (GHG) concentration on net radiation at the surface, which in turn leads to local increased evaporation and vertical instability [Haarsma et al., 2005; Hoerling et al., 2006; Giannini, 2010]. On the other hand, some models project dry conditions as a consequence of the global ocean warming, which heats the troposphere and imposes stability, reducing moisture transport and deep convection over land [Held et al., 2005; Cook and Vizy, 2006; Caminade and Terray, 2010]. In this respect, Bony et al. [2013] pointed out that about half the tropical circulation change projected by the end of the 21 st century, and consequently a large fraction of the regional precipitation change, is independent of global surface warming, but it is rather 
a response to the weaker net radiative cooling of the atmosphere associated with higher atmospheric $\mathrm{CO} 2$ levels affecting the strength of the atmospheric vertical motions. Therefore, the competition between the response of the land-atmosphere system to the local GHG radiative forcing, and the response mediated through the warming of the global SST [Giannini, 2010; Skinner et al., 2012], emerges as a fundamental component of the WAM dynamics and variability, and different sensitivities of climate models to each process appear as a possible explanation of the spread in the projections. Moreover, Biasutti et al. [2009] highlighted that the relationship between the regional atmospheric circulation, particularly the thermal low over the Sahara desert, and Sahel precipitation is generally well reproduced by the coupled models, both in the 20th and the 21st century, while the same models show discrepancies in future projections. The authors argue that the spread in predictions could be also explained through different abilities in reproducing the mechanisms which influence the regional atmospheric circulation.

In this context, the open issues regarding the WAM dynamics and precipitation variability can be conveyed in two main arguments. The first one concerns the detailed comprehension of the physical mechanisms connecting the direct and indirect GHG forcing to the WAM dynamics, and the specific roles of the large scale and regional atmospheric dynamics in modulating this linkage. The second one concerns the assessment of the ability of climate models to simulate the identified physical mechanisms. The objective of this study is to address these issues, by investigating the specific influence of the $\mathrm{CO} 2$ atmospheric concentration on the WAM dynamics. The direct effect of $\mathrm{CO} 2$ concentration increase, and its indirect effect mediated by the global SST warming, are analysed, with a specific focus on the atmospheric dynamics response at the regional and global scale. To this aim, multi-model SST-driven sensitivity experiments are analysed, simulating the present climate under idealized warmer Global Ocean and higher $\mathrm{CO} 2$ atmospheric concentration, respectively. To allow a clear separation of the climate system response, and assess the model sensitivity to the diverse forcings, extreme conditions are imposed in the sensitivity experiments. SSTdriven simulations are preferred to coupled simulations to minimize the problems affecting the coupled models in correctly locating the Sahelian monsoonal precipitation, due to SST biases in the equatorial Atlantic [Roehrig et al., 2013].

The paper is structured as follow: models and data analysed are presented in Section 2; the response of monsoonal precipitation and circulation in the idealized experiments is presented 
in Section 3; the modifications in the global and regional dynamics associated to the WAM are discussed in Section 4 and 5, respectively; finally, conclusions are drawn in Section 6.

\section{Model simulations}

The JAS WAM variability and dynamics are studied by analysing numerical experiments from a set of 12 state-of-the-art atmospheric-ocean coupled models selected in the CMIP5 archive [Taylor et al., 2012] (see Table 1 for details on the models). In the control simulation (CTL), the models are run in atmospheric-only configuration, with prescribed observed SST and sea ice for the period 1979 to the present. Moreover, the simulation includes the observed evolution in the atmospheric composition (including $\mathrm{CO} 2$ ), due to both anthropogenic and natural influences; and the changes in solar forcing, emissions or concentrations of aerosols, and land use. The CTL simulation is the baseline for two sensitivity experiments run either by prescribing uniform $4 \mathrm{~K}$ increase in global SST (4K experiment), or by quadrupling the $\mathrm{CO} 2$ atmospheric concentration while maintaining the SST unchanged. (4xCO2 experiment). The experimental setup is described in detail in Taylor et al. [2012]. Imposing extreme idealized forcing in the sensitivity experiments allows to maximise the impacts and extract the slow response of the climate system to the global SST warming (in $4 \mathrm{~K}$ ), and the fast response to the local direct $\mathrm{CO} 2$ radiative forcing (in $4 \mathrm{xCO} 2$ ), respectively. The $4 \mathrm{xCO} 2$ and $4 \mathrm{~K}$ idealized forcings can be considered extreme in comparison with the observed changes in $\mathrm{CO} 2$ concentration (+40\% since 1750) and SST (+0.7 K in the period 1880-2012) from the preindustrial through the historical period [IPCC, 2014]. However, the idealized scenarios used in this study are comparable with the situation expected in 2100 in the RCP8.5 emission scenario, with the CO2 concentration augmented from 390 ppm in 2011 to more than 1000 ppm (more than $+260 \%$ ), and more than $3 \mathrm{~K}$ global SST warming [IPCC, 2014]. RCP8.5 is an extreme scenario with a radiative forcing reaching $8.5 \mathrm{~W} / \mathrm{m}^{-2}$ in 2100 [Riahi et al., 2011].

To ensure that multi-model mean results are not biased towards models for which more realisations are available, for each model only one realisation of each experiment is used. This "one model-one vote" concept [Santer et al., 2009] has been proved successful for detection of Sahel rainfall significant anomalies in CMIP3 and CMIP5 climate scenarios [Monerie et al., 2012]. The selection of models is based on the experiments availability, considering only models for which the three experiments are available. The differences in grid resolution among models are harmonised by regridding all the datasets to a T42 $\left(\sim 2.8^{\circ}\right)$ 
Gaussian grid. The simulations are analysed over a 30-year period from 1979 to 2008, and averaging precipitation and atmospheric fields in JAS. The response of the WAM precipitation and dynamics to idealized conditions is studied by comparing the sensitivity experiments to the CTL simulation, and significant differences in means are detected through a Student's t-test at 95\% confidence level. A comprehensive evaluation of the individual models' performances is beyond the scope of the paper. However, the biases of the models for some variables describing the WAM dynamics are presented and discussed in the Supplementary Material, along with the response of the individual models in the sensitivity experiments.

\section{Monsoonal circulation and precipitation response}

In Figure 1, the observed and MMM precipitation fields are presented. Precipitation simulated in the CTL experiment is compared to the Global Precipitation Climatology Project version 2.2 (GPCP) dataset [Adler et al., 2003], which contains a monthly analysis of global surface precipitation at $2.5^{\circ}$ resolution from January 1979 to the present. GPCP analysis merges precipitation estimates from satellite products and surface rain gauge observations, and it shows good reliability at seasonal time scale and better performances than satelliteonly products [Nicholson et al., 2003]. Moreover, GPCP has the clear advantage of extending the precipitation analysis to the ocean, allowing a better comparison with model simulations. The MMM of the CTL simulation (Figure 1b) reproduces the main spatial structures of the observed WAM precipitation (Figure1a), with a general underestimation of the seasonal mean (Figure 1c). The precipitation amount averaged in the domain $\left[5^{\circ}-20^{\circ} \mathrm{N}, 20^{\circ} \mathrm{W}-30^{\circ} \mathrm{E}\right]$ including the JAS precipitation belt over West Africa, is $5.1 \mathrm{~mm} /$ day in the GPCP dataset, with $0.5 \mathrm{~mm} /$ day standard deviation (STD). In the CTL simulation, the MMM is $4.1 \mathrm{~mm} /$ day, around $1 \mathrm{~mm} /$ day lower than the observed precipitation, and the multi-model spread ranges in $[2.4,6.7] \mathrm{mm} /$ day, with $1.2 \mathrm{~mm} /$ day STD. Moreover, the CTL simulation is strongly biased in proximity of the climatological rainfall maxima, over western Sahel $(-3.8 \mathrm{~mm} /$ day around $\left.10^{\circ} \mathrm{N}, 15^{\circ} \mathrm{W}\right)$ and Nigeria and Cameroun $\left(-6.6 \mathrm{~mm} /\right.$ day around $\left.5^{\circ} \mathrm{N}, 10^{\circ} \mathrm{E}\right)$, revealing a general inability of the models to fully capture the spatial variability of precipitation (see also individual model biases presented in the Supplementary Material, Figure S1). The origin of this limitations may be attributed to shortcomings in the model physics, such as the inaccurate representation of clouds, energy fluxes, coupling at the surface, and convection at the sub-grid scale, but also to the coarse resolution of the global climate models, which is 
insufficient to simulate the mesoscale convection characterizing the WAM precipitation. These biases underline the urgent need for improvement in the simulation of the climatological WAM precipitation. However, they do not compromise the objective of this study, which is focused on the understanding of the WAM dynamics response in idealized climate conditions, rather than on making quantitative predictions.

Results for 4K experiment (Figure 1d) show a dry response in the Sahel to SST warming, with dryer conditions over western Sahel. On the contrary, 4xCO2 experiment (Figure 1e) shows wet conditions in the Sahel, with the strongest response to CO2 increase over centraleastern Sahel. These responses to idealized conditions are in line with previous results on the influence of SST warming [Held et al., 2005; Cook and Vizy, 2006; Caminade and Terray, 2010] and GHG increase [Haarsma et al., 2005; Hoerling et al., 2006; Giannini, 2010] on WAM precipitation. The modifications in the precipitation patterns are detailed for the individual models by computing a regional rainfall index for the Sahel, the Sahelian rainfall index (SRI) in the domain $\left[10^{\circ}-20^{\circ} \mathrm{N}, 20^{\circ} \mathrm{W}-30^{\circ} \mathrm{E}\right]$, and two sub-regional indices for western $\left[20^{\circ} \mathrm{W}-0^{\circ} \mathrm{E}\right]$ and eastern $\left[0^{\circ}-30^{\circ} \mathrm{E}\right]$ Sahel. In the $4 \mathrm{~K}$ simulation (Figure $2 \mathrm{a}$ ), all the models show significant negative SRI differences with CTL, the MMM difference is $-0.6 \mathrm{~mm} /$ day, and the multi-model spread ranges between -1.1 and $-0.3 \mathrm{~mm} /$ day $(0.3 \mathrm{~mm} /$ day STD). In western Sahel (Figure 2b), the $4 \mathrm{~K}$ MMM response decreases to $-0.8 \mathrm{~mm} /$ day, and differences are significant in all the models, comprised in [-1.7, -0.2] $\mathrm{mm} /$ day $(0.5 \mathrm{~mm} /$ day STD). In eastern Sahel (Figure 2c), differences are significant in 10 out of 12 models, ranging in [-1.0, $0.0] \mathrm{mm} /$ day $(0.3 \mathrm{~mm} /$ day STD), with a $-0.5 \mathrm{~mm} /$ day MMM difference. Conversely, the SRI response in the $4 \mathrm{xCO} 2 \mathrm{MMM}$ is $+0.5 \mathrm{~mm} /$ day, the multi-model spread ranges from +0.2 to $+0.9 \mathrm{~mm} /$ day $(0.2 \mathrm{~mm} /$ day STD), and the differences are significant in 11 out of 12 models (Figure 2a). In western Sahel (Figure 2b), the 4xCO2 MMM response decreases to +0.3 $\mathrm{mm} /$ day, and differences are significant in 5 out of 12 models, ranging in $[0.0,+0.8] \mathrm{mm} /$ day $(0.3 \mathrm{~mm} /$ day STD). In eastern Sahel (Figure 2c), the 4xCO2 MMM response increases to $+0.7 \mathrm{~mm} /$ day, and differences are significant in 11 out of 12 models, ranging in $[+0.2,+1.2]$ $\mathrm{mm} /$ day $(0.3 \mathrm{~mm} /$ day STD). The substantial multi-model agreement on the sign of the precipitation responses confirms the robustness of the simulated precipitation patterns in response to the SST and CO2 idealized forcings. However, the spread in the multi-model response suggests possible higher sensitivity in individual models to one of the two forcings. The relative importance of the SST warming and CO2 increase in influencing the Sahelian precipitation is assessed by computing the sensitivity of the SRI to the global surface 
warming induced by the idealized forcings, i.e., the ratio between the changes in SRI and global surface temperature averaged between $50^{\circ} \mathrm{S}$ and $70^{\circ} \mathrm{N}$. It results that, in the $4 \mathrm{xCO} 2$ experiment, sensitivity is $+1.27 \mathrm{~mm} / \mathrm{day} / \mathrm{K}$ in the MMM. This is, in absolute value, 9 times higher than in $4 \mathrm{~K}$ experiment, showing $-0.14 \mathrm{~mm} /$ day/K in the MMM. A prominent influence of the direct $\mathrm{CO} 2$ forcing on the Sahelian precipitation is evident, although differences in the individual model sensitivity are sizable, ranging from $+0.53 \mathrm{~mm} /$ day/K in FGOALS-g2 (3 times higher than in the $4 \mathrm{~K}$ experiment, $-0.16 \mathrm{~mm} /$ day $/ \mathrm{K}$ ) to $+2.17 \mathrm{~mm} /$ day $/ \mathrm{K}$ in HadGEM2A (24 times higher than in the $4 \mathrm{~K}$ experiment, $-0.09 \mathrm{~mm} / \mathrm{day} / \mathrm{K}$ ).

In addition, it is interesting to notice how, from the superimposition of the responses to SST warming and $\mathrm{CO} 2$ increase, the main features of the projected changes in Sahelian precipitation emerge, namely dry anomalies over western Sahel and wet conditions over central-eastern Sahel [Biasutti, 2013; Monerie et al., 2013; Roehrig et al., 2013]. A descriptive illustration is presented in Figure 3, where the 4K-CTL and 4xCO2-CTL precipitation differences (Figures 1d, e) are combined and compared with the 21 st century projection simulated by the same models, run in the coupled setup, for the RCP8.5 emission scenario. The combination of the $4 \mathrm{~K}$ and $4 \mathrm{xCO} 2$ responses (Figure $3 \mathrm{a}$, computed as the sum of the precipitation patterns displayed in Figures 1d, e) exhibits positive precipitation anomalies in central Sahel (up to around $+0.5 \mathrm{~mm} /$ day) and the Tropical Atlantic around $5^{\circ} \mathrm{N}$ (up to around $+1 \mathrm{~mm} /$ day), and dry anomalies in western Sahel (down to around $-2 \mathrm{~mm} /$ day) and the eastern part of the Guinean coast (down to around $-0.5 \mathrm{~mm} / \mathrm{day}$ ). In the RCP8.5 scenario, at the end of the 21st century, wet anomalies are expected in central-eastern Sahel (up to around $+1 \mathrm{~mm} /$ day) and the Tropical Atlantic around $5^{\circ} \mathrm{N}$ (up to around $+2 \mathrm{~mm} /$ day), and dry anomalies are projected in western Sahel (down to around $-0.5 \mathrm{~mm} /$ day) and the Guinea coast (down to around $-1.5 \mathrm{~mm} /$ day). Whereas the anomaly patterns are different in amplitude and local features, the main spatial structures appear similar. This suggests that the future projected pattern may result from the competition between the different actions of the $\mathrm{CO} 2$ forcing on the land-atmosphere system. On the one hand, the indirect action conveyed by the SST warming, which heats the troposphere, imposing stability and reducing deep convection over land [Caminade and Terray, 2010]. On the other hand, the direct action on the local radiative balance, producing a weaker net radiative cooling of the atmosphere, a warming of the land surface and a change in the land-sea thermal gradient, which is favourable to the strengthening of large-scale upward motions [Bony et al., 2013]. The evidence of the contrasting effects of the $\mathrm{CO} 2$ forcing on the WAM precipitation, along with 
the different sensitivity shown by individual models, point out the importance of understanding the balance between the competing actions of the SST warming and $\mathrm{CO} 2$ increase and improving the climate model ability in correctly simulate this balance. It is also worth noticing that the superimposition pattern in Figure 3 is consistent with the precipitation anomalies expected during positive phases of the SHL [Lavaysse et al., 2010b; Evan et al., 2015].

The monsoonal flow in the lower troposphere is depicted in Figure 4 through the horizontal wind field and the divergence of the moisture transport at $925 \mathrm{hPa}$. The CTL simulation shows the intertropical discontinuity (ITD) between the southwesterly moist flow from the tropical Atlantic and the northerly dryer flow crossing the Sahara [Issa Lélé and Lamb, 2010], and the associated moisture convergence over the Sahel (Figure 4a). The response of the models to the SST warming is a general weakening of the monsoonal circulation, with no significant changes over the Sahel, accompanied by a slight southward displacement of the moisture transport convergence (Figure 4b). The shift of the latitudinal position of the moisture transport convergence over West Africa is assessed by identifying the mean position of the divergence minimum in the longitudinal domain $\left[10^{\circ} \mathrm{W}-30^{\circ} \mathrm{E}\right]$. The shift in the minimum is $-0.5^{\circ}$ in the MMM, it is negative in 9 out of 12 models, and the multi-model spread ranges between $-1.8^{\circ}$ and $+1.0^{\circ}\left(0.7^{\circ} \mathrm{STD}\right)$. Given the small modifications in the wind field, the changes in the moisture convergence can be attributed to the general moistening of the lower troposphere produced by the SST warming (not shown). On the contrary, the massive injection of $\mathrm{CO} 2$ in the atmosphere produces a sizable strengthening of the westerly flow from the Atlantic across the Sahel, and a slight reinforcement of the northerly flow from the Mediterranean, resulting in a clear northward displacement of the moisture convergence belt over the Sahel (Figure 4c). The shift is $+1.1^{\circ}$ in the MMM, is positive in 11 out of 12 models, ranging in $\left[0.0^{\circ},+3.6^{\circ}\right]\left(0.9^{\circ}\right.$ STD $)$.

\section{Response at the global scale}

The competition between the direct and indirect effects of $\mathrm{CO} 2$ concentration increase in modifying circulation and precipitation in the global Tropics has been investigated by Bony et al. [2013]. By separating the precipitation changes in a dynamic component related to modifications in large scale circulation and a thermodynamic one independent of these, they demonstrated that about half the changes projected in tropical circulation and regional 
precipitation by the end of the 21 st century is independent of global surface warming. In Figure 5, the global net radiative balance, defined at the top of the atmosphere as the difference between the downward shortwave radiation and the sum of upward shortwave and longwave radiation, is presented for CTL and sensitivity experiments. The CTL experiment (Figure 5a) represents the warming of the atmosphere in the Tropics and sub-Tropics, with cooling over the desert belt in the Northern Hemisphere, and in the extra-Tropics (north of $45-50^{\circ} \mathrm{N}$ and south of $10-15^{\circ} \mathrm{S}$ ). In the $4 \mathrm{~K}$ simulation (Figure $5 \mathrm{~b}$ ), a generalized net radiative cooling of the atmosphere is found, reaching $-16 \mathrm{~W} / \mathrm{m}^{2}$ in the Sahara, which is ascribed to the increase in losses of longwave radiation associated to the surface warming (not shown). On the contrary, the increased $\mathrm{CO} 2$ concentration produces a net radiative warming in $4 \mathrm{xCO} 2$ (Figure $5 \mathrm{c}$ ), reaching $+14 \mathrm{~W} / \mathrm{m}^{2}$ in the Sahara, which is associated with reduced losses in both longwave and shortwave radiation (not shown).

The response in the lower troposphere to the changes in the radiative balance is studied through the moist and dry static energy (MSE and DSE, respectively) content in the lower troposphere integrated between 925 and $700 \mathrm{hPa}$. The MSE is defined as

$$
M S E=g z+C_{p} T+L q,
$$

where $g z$ is the geopotential energy (with $g$ the gravitational acceleration and $z$ the geopotential height), $C_{p} T$ the enthalpy (with $C_{p}$ the specific heat of dry air at constant pressure and $T$ the temperature), and $L q$ is the latent energy associated with evaporation and condensation of water (with $L$ the latent heat of evaporation and $q$ the specific humidity). As transformation of enthalpy and latent energy available in the lower troposphere into geopotential energy in the upper levels is the main signal of convection, MSE is directly related to monsoonal precipitation [Fontaine and Philippon, 2000]. The DSE accounts for only enthalpy and geopotential energy. The differences between sensitivity and CTL experiments are presented in Figure 6. The CTL simulation shows a maximum in the tropical belt, which is associated to the latent heat content, while DSE is more important over the subtropical continental surfaces (Figure $6 \mathrm{a}, \mathrm{b}$ ). The surface warming in $4 \mathrm{~K}$ produces a global and almost uniform increase of MSE, with a maximum over the northern Tropics, which is associated to the changes in the latent heat content (Figure 6c, d). On the contrary, the response to increased $\mathrm{CO} 2$ concentration in $4 \mathrm{xCO} 2$, although weaker, shows a clear relationship with the changes in the DSE content, resulting in a meridional gradient and well localized maxima over the Sahel, the Arabian Peninsula, southwestern and eastern Asia, and North America (Figure 6e, f). It appears that the response of MSE to the SST warming is 
mostly associated to the change of moist component at the global scale, while the response in the $4 \mathrm{xCO} 2$ experiment is driven by the modifications in the dry component localized over the northern continental masses.

The main features of the 3D large scale circulation affecting the WAM variability are studied by analysing the meridional circulation, displayed through meridional wind and the vertical velocity averaged in the domain $\left[10^{\circ} \mathrm{W}, 10^{\circ} \mathrm{E}\right]$ to include southern Atlantic Ocean and West Africa (Figure 7), and the zonal circulation, displayed through zonal wind and vertical velocity averaged in the domain $\left[5^{\circ} \mathrm{N}, 20^{\circ} \mathrm{N}\right]$, to include Sahel and northern Tropics (Figure $8)$.

The CTL simulation captures the main features of the meridional circulation over southern Atlantic and West Africa, illustrating the northern and southern overturning cells associated to the meridional Hadley circulation, along with the deep convection associated to the ITCZ around $10^{\circ} \mathrm{N}$ and the convergence in the lower troposphere over the Sahel associated to the monsoonal circulation (Figure 7a). By comparing CTL with the sensitivity experiments, it is seen that the SST warming weakens the southern overturning cell, resulting in a reduction of the deep convection over Guinea and Sahel (Figure 7b). On the contrary, in 4xCO2 the southern overturning cell is reinforced along with deep convection over the Sahel, and the lower troposphere convergence move northward into the Sahara (Figure 7c).

The zonal circulation over the northern Tropics is dominated by upward motions associated with the WAM dynamics and induced by the oceanic warm pools in the Indian Ocean and in western and eastern Pacific (Figure 8a). Moreover, the Tropical easterly jet (TEJ) axis is recognizable in the upper troposphere over Africa and the Indian Ocean, along with the westerly flow in the lower troposphere over the Indian Ocean associated to the Indian summer monsoon (Figure 8a). The TEJ intensity is strongly related to the precipitation variability, wet conditions in the Sahel being concomitant with stronger than average TEJ and vice versa [Nicholson, 2013]. The sensitivity experiments show anomalous ascending motions as a response to SST warming over the western Pacific and anomalous subsidence over Africa and Indian Ocean, along with a weakening of the TEJ (Figure 8b). The change in the TEJ intensity is assessed over West Africa by averaging the zonal wind at $200 \mathrm{hPa}$ in the domain $\left[5^{\circ}-15^{\circ} \mathrm{N}, 20^{\circ} \mathrm{W}-30^{\circ} \mathrm{E}\right]$. It results that, in the $4 \mathrm{~K} \mathrm{MMM}$, the TEJ is $4.7 \mathrm{~m} / \mathrm{s}$ weaker than in the CTL run, and the multi-model response ranges in $[+0.5,+10.1] \mathrm{m} / \mathrm{s}(2.8 \mathrm{~m} / \mathrm{s}$ 
STD). Conversely, the 4xCO2 experiment simulates weaker upward motions in the western and eastern Pacific, and an anomalous organized zonal cell over the Africa-Atlantic sector, with a westerly flux in the lower troposphere into West Africa (see also Figure 4c) and a stronger TEJ (Figure 8c). In the $4 \mathrm{xCO} 2$ experiment, the MMM response is $-2.9 \mathrm{~m} / \mathrm{s}$, and the multi-model response ranges in $[-3.75,-0.12] \mathrm{m} / \mathrm{s}(0.97 \mathrm{~m} / \mathrm{s}$ STD $)$.

The response of the teleconnection patterns is explored through the global velocity potential and associated divergent wind at $200 \mathrm{hPa}$ (Figure 9). The CTL simulation shows a divergence-convergence dipole between western Pacific and southern Atlantic (Figure 9a), which is the dominant teleconnection pattern in boreal summer [Tanaka et al., 2004]. The sensitivity experiments confirm the responses seen in the zonal circulation, with a general weakening of the global teleconnection pattern in $4 \mathrm{~K}$ (Figure 9b), and a divergenceconvergence anomaly between tropical Africa and Atlantic, indicating an intensification of the teleconnection over Africa in 4xCO2 (Figure 9c).

The analysis of the response of the global dynamics fields and the modifications in the Sahelian precipitation connections suggests that the increase in $\mathrm{CO} 2$ concentration favours the meridional circulation and the zonal connectivity in the tropical belt, by forcing a meridional energy gradient. Meridional circulation and zonal connectivity are conversely weakened by a warmer Global Ocean, which produces an energy excess in the tropical belt.

\section{Response of the regional drivers}

In this section the impact of the SST and CO2 idealized forcings on the WAM regional drivers is discussed, by analysing the modifications in the most relevant features of the atmospheric circulation over West Africa, and the changes in their relationship with the Sahelian precipitation.

The response of the SHL is first analysed, by computing the 925-700 hPa thickness (Z925700), which measures the thermal expansion of the lower troposphere [Lavaysse et al., 2009] The CTL simulation well reproduces the climatological location of SHL over western Sahara (Figure 10a). The 4K experiment is characterized by a general thickening of the lower troposphere compared to CTL (Figure 10b), which is consistent with the global warming of the surface associated with the forcing SST pattern (not shown). A peak in thickness is 
evident along $15^{\circ} \mathrm{N}$ (around $+60 \mathrm{~m}$ ), which inhibits the penetration of the monsoonal flow and rainfall inland compared to CTL (see Figure 1d). The SHL latitudinal position is identified as the mean position of the Z925-700 maximum in the longitudinal domain $\left[10^{\circ} \mathrm{W}\right.$, $\left.10^{\circ} \mathrm{E}\right]$. In the $4 \mathrm{~K}$ simulation, 10 out of 12 models show a southward shift, and the multimodel spread ranges in $\left[-2.0^{\circ},+0.6^{\circ}\right],\left(0.7^{\circ} \mathrm{STD}\right)$, resulting in a $-0.7^{\circ}$ meridional displacement in the MMM. On the contrary, the $4 \mathrm{xCO} 2$ experiment presents a significant warming over land in the boreal summer hemisphere, resulting in thermal anomalies over the continental surface in North America, Eurasia and the Sahara (not shown). As a consequence of the Sahara desert warming, thickness over West Africa shows a meridional gradient (from around $0 \mathrm{~m}$ in the Sahel to around $+17 \mathrm{~m}$ along the Mediterranean southern coast, see Figure 10c), which is favourable to the northward displacement of the precipitation belt (see Figure 1e). The SHL displacement is $+1.0^{\circ}$ northward in the $4 \mathrm{xCO} 2 \mathrm{MMM}$, comprised in $\left[0.0^{\circ}\right.$, $\left.+2.6^{\circ}\right]\left(0.9^{\circ} \mathrm{STD}\right)$ in the multi-model ensemble. The comparison between $4 \mathrm{~K}$ and $4 \mathrm{xCO} 2$ changes in thickness shows a larger thickening in $4 \mathrm{~K}$ everywhere in West Africa, which is associated with reduced precipitation, pointing to the importance of the regional pattern of the modifications, in spite of the mere amplitude.

The modifications in the MSE and DSE content in the lower troposphere are detailed for West Africa by computing the meridional profile in the domain $\left[10^{\circ} \mathrm{W}-10^{\circ} \mathrm{E}\right]$, to emphasize the land-sea contrast between West Africa and southern Atlantic (Figure 11). Differences between sensitivity experiments and CTL show a general and significant MSE increase in all the $4 \mathrm{~K}$ models, from tropical Atlantic to Sahara and peaking over the coast of Guinea (Figure 11a). On the contrary, the modifications simulated in the $4 \mathrm{xCO} 2$ experiment are in general smaller, with all the models simulating significant and positive differences over the African continent and peaking over the Sahel, and no significant differences over the ocean (Figure 11b). When DSE is selected (Figure 11c, d), it results that the meridional profile is dominated in both the experiments by the latent heat associated with evaporation. Enthalpy over Sahara desert is important in maintaining the MSE meridional gradient in $4 \mathrm{xCO} 2$, but in $4 \mathrm{~K}$ it is not enough to produce a significant meridional gradient. In spite of the larger availability of MSE in the $4 \mathrm{~K}$ experiment compared to $4 \mathrm{xCO} 2$, the simulated profile is less favourable to the inland progression of the monsoonal circulation, because of the peak around the Guinea coast, which prevents the monsoonal flow to penetrate inland (Figure 11c). In comparison with the CTL simulations, the maximum of the MSE meridional profile is shifted $1.2^{\circ}$ southward in the MMM, comprised between $-2.4^{\circ}$ and $0.0^{\circ}\left(0.7^{\circ} \mathrm{STD}\right)$ in the multi-model 
ensemble. On the contrary, the $4 \mathrm{xCO} 2$ profiles show a clear meridional gradient from the Atlantic to the Sahel, which is more favourable to the monsoonal dynamics (Figure 11d). The MSE maximum results northward shifted by $0.7^{\circ}$, ranging in $\left[+0.0^{\circ},+1.6^{\circ}\right]\left(0.5^{\circ}\right.$ STD $)$ in the multi-model ensemble. Furthermore, this enhanced energy meridional gradient is also consistent with the anomalous zonal circulation over West Africa displayed in Figure 7c.

The zonal wind at $600 \mathrm{hPa}$ is analysed to portray the African easterly jet (AEJ), which is a key element in the WAM dynamics. The AEJ develops in response to the meridional thermal gradient over West Africa, with an east-west orientation along $12^{\circ} \mathrm{N}$ [Cook, 1999], and is maintained by the meridional circulations associated with the monsoon, namely the Hadley circulation and the SHL [Thorncroft and Blackburn, 1999; Chen, 2005]. The AEJ variability influences the intensity and position of the WAM precipitation pattern, with a stronger (weaker) than average jet associated to negative (positive) rainfall anomalies over Sahel, and a northern (southern) displacement associated to a more (less) inland penetrating monsoonal flow [Cook, 1999]. Moreover, AEJ may modulate the WAM precipitation through the synoptic activity of the African easterly waves (AEW) on its southern flank, along $10^{\circ} \mathrm{N}$ [Diedhiou et al., 1999; Fink, 2003]. The main axis of the AEJ is correctly reproduced in the CTL simulation (Figure 12a). The 4K experiment shows stronger (weaker) easterly winds south (north) of $10^{\circ} \mathrm{N}$, corresponding to a southern displacement of the AEJ, while the opposite pattern is found in the $4 \mathrm{xCO} 2$ experiment (Figure 12b, c). The modifications in the AEJ location in the sensitivity experiments are estimated by determining the mean latitudinal position of the minimum of the zonal wind at $600 \mathrm{hPa}$ in the longitudinal domain $\left[20^{\circ} \mathrm{W}\right.$, $\left.30^{\circ} \mathrm{E}\right]$. As a result, the AEJ shifts southward by $-3.0^{\circ}$ in the $4 \mathrm{~K} \mathrm{MMM}$, and the multi-model spread ranges is $\left[-5.3^{\circ},-0.2^{\circ}\right]\left(1.5^{\circ} \mathrm{STD}\right)$. In the $4 \mathrm{xCO} 2$ experiment, the shift in the MMM is $+1.2^{\circ}$, ranging in $\left[+0.0^{\circ},+2.5^{\circ}\right]\left(0.8^{\circ} \mathrm{STD}\right)$. The modifications in the AEJ dynamics are consistent with the precipitation changes displayed in Figure 1 and also a linkage with the meridional energy profiles in Figure 11 appears evident, being the stronger enthalpy gradient more favourable to a northward displaced jet in the $4 \mathrm{xCO} 2$ experiment.

The linkage between the Sahelian precipitation and the thermal forcing over West Africa is studied by analysing the correlation between the SRI and the meridional gradient of Z925700 over West Africa, which is constructed by subtracting Z925-700 averaged north and south of $20^{\circ} \mathrm{N}$ in the domain $\left[20^{\circ} \mathrm{W}-30^{\circ} \mathrm{E}, 0^{\circ}-40^{\circ} \mathrm{N}\right]$. The positive relationship is significant and strong in ERAI at the interannual time scale $(r=0.75)$, and is captured by CTL in the 
MMM ( $\mathrm{r}=0.55)$ and in 8 out of 12 models (Table 2). The relationship is robust both in $4 \mathrm{~K}$ and $4 \mathrm{xCO} 2$ (significant in 9 out of 12 , and 10 out of 12 models, respectively), with $4 \mathrm{xCO} 2$ showing higher correlations than $4 \mathrm{~K}$ in the MMM $(r=0.73$ and $r=0.52$, respectively $)$ and in 9 out of 12 models (Table 2).

The coherence between precipitation and regional monsoonal circulation is studied by correlating the SRI and the West African Monsoon Index (WAMI), which is defined in the domain $\left[20^{\circ} \mathrm{W}-20^{\circ} \mathrm{E}, 3^{\circ}-13^{\circ} \mathrm{N}\right]$ as the difference between the standardized wind modulus at $850 \mathrm{hPa}$ and the standardized zonal wind at $200 \mathrm{hPa}$ [Garric et al., 2002]. The WAMI is used as an indicator of the intensity of the regional monsoonal cell, and is positively correlated to the Sahel precipitation at the interannual time scale [Fontaine et al., 1995]. GPCP data and ERAI reanalysis confirm the correlation for the period 1979-2008 $(\mathrm{r}=0.77)$, and CTL simulations partially reproduce the correlation $(r=0.46$ in the MMM), with 7 out of 12 models showing significant positive correlations (Table 2). Interestingly, in the $4 \mathrm{~K}$ experiment the relationship is even less robust than in CTL $(r=0.34$ in the MMM, significant in 4 out of 12 models), while robustness is recovered in $4 \mathrm{xCO} 2(\mathrm{r}=0.61$ in the MMM, significant in 11 out of 12 models), with 10 out of 12 models showing higher correlations than in $4 \mathrm{~K}$ (Table 2).

Finally, the changes in relationship between the mid-troposphere regional circulation and the Sahelian precipitation are studied by analysing the correlation between SRI and AEJ, which is represented through the zonal wind at $600 \mathrm{hPa}$. The positive correlation between precipitation and intensity and meridional displacement over West Africa of the AEJ is illustrated in the CTL simulation, showing positive (negative) correlations along the $10^{\circ} \mathrm{N}$ $\left(18^{\circ} \mathrm{N}\right)$ axis (Figure 13a). When the correlation is computed in the sensitivity experiments, the general pattern is conserved in both $4 \mathrm{~K}$ and $4 \mathrm{xCO} 2$, but significance is strongly reduced in the former, while the signal is robust in the latter, where the axis over West Africa is also better represented (Figure 13b, c).

The analysis of the WAM regional drivers points out the strong impact of the idealized forcings on the main features of the regional dynamics, namely the SHL, the meridional energy gradient, and the AEJ. Specifically, the CO2 concentration increase is particularly effective in modifying the dynamics over the Sahara desert, favouring the mechanisms associated with wet conditions in the Sahel. Furthermore, while the SST warming appears to 
weaken the linkage between precipitation and regional dynamics, the $\mathrm{CO} 2$ increase clearly strengthens the coupling.

\section{Summary and conclusions}

In this study, the mechanisms linking the WAM dynamics to the $\mathrm{CO} 2$ forcing are investigated. To this aim, extreme idealized conditions are imposed in multi-model climate simulations to maximise and clearly separate the response of the WAM dynamics to the opposite and competing effects induced by $\mathrm{CO} 2$. On the one hand, the effect of the direct radiative forcing, which tends to reinforce the monsoonal circulation, is studied in sensitivity experiments run with prescribed observed SST and quadrupled CO2 concentration. On the other hand, the indirect $\mathrm{CO} 2$ effect mediated by the global SST warming, which weakens the monsoon, is studied in sensitivity experiments where the global SST is uniformly increased by $4 \mathrm{~K}$.

\section{The precipitation response over Sahel shows opposite modifications, with dry conditions} associated with the SST warming $(-0.6 \mathrm{~mm} /$ day in the Sahel, down to $-0.8 \mathrm{~mm} /$ day in western Sahel), while increased $\mathrm{CO} 2$ concentration leads to wet anomalies $(+0.5 \mathrm{~mm} /$ day in the Sahel, up to $+0.7 \mathrm{~mm} /$ day in eastern Sahel). Moreover, the modifications in the precipitation patterns appear associated with coherent modifications in the monsoonal circulation, namely in the meridional thermal forcing, the monsoonal flow in the lower troposphere, the AEJ and TEJ intensity and position, and in the regional meridional overturning circulation.

The analysis of dynamics aspects reveals that the global SST warming acts at the global scale, weakening the connection between precipitation and the regional drivers. A warmer Global Ocean reinforces evaporation in the Tropics, resulting in an inhibition of the monsoonal flow and the ITCZ migration over West Africa. Conversely, the CO2 increase strengthens the coupling between precipitation and the regional dynamics over West Africa. The local atmospheric radiative forcing, resulting from the direct action of the $\mathrm{CO} 2$ increase, warms the Sahara and enhances evaporation over the Sahel, producing specific humidity anomalies in the low troposphere. The consequent increase in the low tropospheric latent heat and enthalpy content over Sahara and Sahel reinforces the MSE meridional gradient over West Africa, leading to more intense monsoonal circulation and precipitation. More specifically, the westerly flow over the Sahel is reinforced, accompanied by a northward shift 
in moisture convergence $\left(+0.6^{\circ}\right)$ and AEJ $\left(+2.7^{\circ}\right)$. Upward anomalies are seen in the vertical motions over the Sahel and the Sahara, which are associated with a strengthening of the meridional overturning circulation, and a $1^{\circ}$ northward displacement of the SHL, respectively. Finally, the anomalous westerly flow in the lower troposphere, and a reinforced TEJ $(+2.9 \mathrm{~m} / \mathrm{s})$, connect a coherent zonal circulation cell over West Africa. In this picture, the modifications in the atmospheric dynamics over the Sahara appear to be particularly important. A schematic of the WAM dynamics and precipitation in the idealized simulations is presented in Figure 14.

The general agreement among models in their response to the idealized conditions demonstrates the robustness of the identified mechanisms linking the WAM dynamics to the SST and CO2 idealized forcings, and reflects the fact that the simulation of these mechanisms does not depend on the model physics, nor on the model performance. This robustness also confirms the value of using idealized forcings to maximise and separate the response of the climate system. Furthermore, the similarity of the future projections in the RCP8.5 scenario with the combined responses in the $4 \mathrm{~K}$ and $4 \mathrm{xCO} 2$ simulations, though only qualitative, clearly shows how the competition between the global SST warming and the CO2 increase is a key factor in driving the WAM variability and change. Indeed, it is argued that the large spread in the simulation of the WAM dynamics and precipitation may be related to an unbalanced model response to the direct and indirect $\mathrm{CO} 2$ forcings, i.e., dry (wet) biases may be produced by specific model sensitivity to the SST warming (CO2 increase). The analysed models show different sensitivity to the idealized forcings, leading to a sizable spread in the amplitude of the response. Therefore, the quantitative evaluation of the impact of direct and indirect $\mathrm{CO} 2$ forcings on the WAM dynamics, and the assessment of the model ability to reproduce the amplitude of this impact, still need to be addressed. This could be achieved by analysing model simulations of periods well covered with observations and one of the two mechanisms is clearly dominant. In this respect, the 20th century and/or the mid-Holocene could be optimal candidates to analyse the processes responding to changes in the land-sea contrast, and this will be the subject of a forthcoming study.

\section{Acknowledgements}

This work benefitted from the support of the Agence Nationale de la Recherche (ANR) grant ANR-10-LABX-18-01 of the national Programme Investissements d'Avenir. Funding for this 
600

601

602

603

604

605

606

607

608

609

610

611

612

613

614

615

616

617

618

619

620

621

622

623

624

625

626

627

628

629

630

work was also provided by Laboratoire d'excellence Institut Pierre Simon Laplace (L-IPSL). We acknowledge the World Climate Research Programme's Working Group on Coupled Modelling, which is responsible for CMIP, and we thank the climate modelling groups (listed in Table 1 of this paper) for producing and making available their model output. For CMIP the U.S. Department of Energy's Program for Climate Model Diagnosis and Intercomparison provides coordinating support and led development of software infrastructure in partnership with the Global Organization for Earth System Science Portals. Authors thank A. Evan for useful discussions, and two anonymous reviewers for their insightful comments that have greatly improved the quality of the paper.

\section{References}

Adler, R. F. et al. (2003), The Version-2 Global Precipitation Climatology Project (GPCP) Monthly Precipitation Analysis (1979-Present), J. Hydrometeorol., 4, 1147-1167, doi:10.1175/1525-7541(2003)004<1147:TVGPCP>2.0.CO;2.

Bader, J., and M. Latif (2003), The impact of decadal-scale Indian Ocean sea surface temperature anomalies on Sahelian rainfall and the North Atlantic Oscillation, Geophys. Res. Lett., 30, 1-4, doi:10.1029/2003GL018426.

Biasutti, M. (2013), Forced Sahel rainfall trends in the CMIP5 archive, J. Geophys. Res. Atmos., 118, 1613-1623, doi:10.1002/jgrd.50206.

Biasutti, M., A. H. Sobel, and S. J. Camargo (2009), The Role of the Sahara Low in Summertime Sahel Rainfall Variability and Change in the CMIP3 Models, J. Clim., 22, 5755-5771, doi:10.1175/2009JCLI2969.1.

Bony, S., G. Bellon, D. Klocke, S. Sherwood, S. Fermepin, and S. Denvil (2013), Robust direct effect of carbon dioxide on tropical circulation and regional precipitation, Nat. Geosci., 6, 447-451, doi:10.1038/ngeo1799.

Caminade, C., and L. Terray (2010), Twentieth century sahel rainfall variability as simulated by the ARPEGE AGCM, and future changes, Clim. Dyn., 35, 75-94, doi:10.1007/s00382-009-0545-4.

Chauvin, F., R. Roehrig, and J. P. Lafore (2010), Intraseasonal variability of the saharan heat low and its link with midlatitudes, J. Clim., 23, 2544-2561, doi:10.1175/2010JCLI3093.1.

Chen, T. C. (2005), Maintenance of the midtropospheric North African summer circulation; Saharan high and African easterly jet, J. Clim., 18, 2943-2962, doi:10.1175/JCLI3446.1.

Cook, K. H. (1999), Generation of the African easterly jet and its role in determining West African precipitation, J. Clim., 12, 1165-1184, doi:10.1175/15200442(1999)012<1165:GOTAEJ>2.0.CO;2.

Cook, K. H., and E. K. Vizy (2006), Coupled model simulations of the West African monsoon system: Twentieth- and twenty-first-century simulations, J. Clim., 19, 36813703, doi:10.1175/JCLI3814.1.

Diedhiou, a., S. Janicot, a. Viltard, P. De Felice, and H. Laurent (1999), Easterly wave 
regimes and associated convection over West Africa and tropical Atlantic: Results from the NCEP/NCAR and ECMWF reanalyses, Clim. Dyn., 15, 795-822, doi: $10.1007 / \mathrm{s} 003820050316$.

Evan, A. T., C. Flamant, C. Lavaysse, C. Kocha, and A. Saci (2015), Water Vapor-Forced Greenhouse Warming over the Sahara Desert and the Recent Recovery from the Sahelian Drought, J. Clim., 28, 108-123, doi:10.1175/JCLI-D-14-00039.1.

Fink, A. H. (2003), Spatiotemporal variability of the relation between African Easterly Waves and West African Squall Lines in 1998 and 1999, J. Geophys. Res., 108, 1-17, doi:10.1029/2002JD002816.

Fontaine, B., and N. Philippon (2000), Seasonal Evolution of Boundary Layer Heat Content in the West African Monsoon From the Ncep / Ncar, Int. J. Climatol., 20, 1777-1790.

Fontaine, B., S. Janicot, and V. Moron (1995), Rainfall anomaly patterns and wind field signals over West Africa in August (1958-1989), J. Clim., 8, 1503-1510.

Fontaine, B., J. Garcia-Serrano, P. Roucou, B. Rodriguez-Fonseca, T. Losada, F. Chauvin, S. Gervois, S. Sijikumar, P. Ruti, and S. Janicot (2010), Impacts of warm and cold situations in the Mediterranean basins on the West African monsoon: Observed connection patterns (1979-2006) and climate simulations, Clim. Dyn., 35, 95-114, doi:10.1007/s00382-009-0599-3.

Fontaine, B., M. Gaetani, A. Ullmann, and P. Roucou (2011), Time evolution of observed July-September sea surface temperature-Sahel climate teleconnection with removed quasi-global effect (1900-2008), J. Geophys. Res. Atmos., 116, 1-17, doi:10.1029/2010JD014843.

Gaetani, M., B. Fontaine, P. Roucou, and M. Baldi (2010), Influence of the Mediterranean Sea on the West African monsoon: Intraseasonal variability in numerical simulations, $J$. Geophys. Res., 115, 1-17, doi:10.1029/2010JD014436.

Garric, G., H. Douville, and M. Déqué (2002), Prospects for improved seasonal predictions of monsoon precipitation over Sahel, Int. J. Climatol., 22, 331-345, doi:10.1002/joc.736.

Giannini, A. (2010), Mechanisms of Climate Change in the Semiarid African Sahel: The Local View, J. Clim., 23, 743-756, doi:10.1175/2009JCLI3123.1.

Giannini, A., R. Saravanan, and P. Chang (2003), Oceanic forcing of Sahel rainfall on interannual to interdecadal time scales, Science, 302, 1027-1030, doi:10.1126/science.1089357.

Haarsma, R. J., F. M. Selten, S. L. Weber, and M. Kliphuis (2005), Sahel rainfall variability and response to greenhouse warming, Geophys. Res. Lett., 32, 1-4, doi:10.1029/2005GL023232.

Held, I. M., T. L. Delworth, J. Lu, K. L. Findell, and T. R. Knutson (2005), Simulation of Sahel drought in the 20th and 21st centuries., Proc. Natl. Acad. Sci. U. S. A., 102, 17891-17896, doi:10.1073/pnas.0509057102.

Hoerling, M., J. Hurrell, J. Eischeid, and A. Phillips (2006), Detection and attribution of twentieth-century northern and southern African rainfall change, J. Clim., 19, 39894008, doi:10.1175/JCLI3842.1.

IPCC, (2014), Climate Change 2014: Synthesis Report. Contribution of Working Groups I, II and III to the Fifth Assessment Report of the Intergovernmental Panel on Climate Change [Core Writing Team, R.K. Pachauri and L.A. Meyer (eds.)]. IPCC, Geneva, Switzerland, $151 \mathrm{pp}$. 
Issa Lélé, M., and P. J. Lamb (2010), Variability of the Intertropical Front (ITF) and Rainfall over the West African Sudan-Sahel Zone, J. Clim., 23, 3984-4004, doi:10.1175/2010JCLI3277.1.

Kandji, S. T., L. Verchot, and J. Mackensen (2006), Climate change and variability in the Sahel region: impacts and adaptation strategies in the agricultural sector. UNEP \& ICRAF.

Lavaysse, C., C. Flamant, S. Janicot, D. J. Parker, J. P. Lafore, B. Sultan, and J. Pelon (2009), Seasonal evolution of the West African heat low: A climatological perspective, Clim. Dyn., 33, 313-330, doi:10.1007/s00382-009-0553-4.

Lavaysse, C., C. Flamant, S. Janicot, and P. Knippertz (2010a), Links between African easterly waves, midlatitude circulation and intraseasonal pulsations of the West African heat low, Q. J. R. Meteorol. Soc., 136, 141-158, doi:10.1002/qj.555.

Lavaysse, C., C. Flamant, and S. Janicot (2010b), Regional-scale convection patterns during strong and weak phases of the Saharan heat low, Atmos. Sci. Lett., 11, 255-264, doi:10.1002/asl.284.

Lavaysse, C., J. P. Chaboureau, and C. Flamant (2011), Dust impact on the west african heat low in summertime, Q. J. R. Meteorol. Soc., 137, 1227-1240, doi:10.1002/qj.844.

Losada, T., B. Rodríguez-Fonseca, S. Janicot, S. Gervois, F. Chauvin, and P. Ruti (2010), A multi-model approach to the Atlantic Equatorial mode: Impact on the West African monsoon, Clim. Dyn., 35, 29-43, doi:10.1007/s00382-009-0625-5.

Lu, J., and T. L. Delworth (2005), Oceanic forcing of the late 20th century Sahel drought, Geophys. Res. Lett., 32, L22706, doi:10.1029/2005GL023316.

Meehl, G. A., C. Covey, K. E. Taylor, T. Delworth, R. J. Stouffer, M. Latif, B. McAvaney, and J. F. B. Mitchell (2007), THE WCRP CMIP3 Multimodel Dataset: A New Era in Climate Change Research, Bull. Am. Meteorol. Soc., 88, 1383-1394, doi:10.1175/BAMS-88-9-1383.

Mohino, E., S. Janicot, and J. Bader (2011), Sahel rainfall and decadal to multi-decadal sea surface temperature variability, Clim. Dyn., 37, 419-440, doi:10.1007/s00382-010-08672.

Monerie, P. A., B. Fontaine, and P. Roucou (2012), Expected future changes in the African monsoon between 2030 and 2070 using some CMIP3 and CMIP5 models under a medium-low RCP scenario, J. Geophys. Res. Atmos., 117, 1-12, doi:10.1029/2012JD017510.

Monerie, P.-A., P. Roucou, and B. Fontaine (2013), Mid-century effects of Climate Change on African monsoon dynamics using the A1B emission scenario, Int. J. Climatol., 33, 881-896, doi:10.1002/joc.3476.

Nicholson, S. E. (2013), The West African Sahel: A Review of Recent Studies on the Rainfall Regime and Its Interannual Variability, ISRN Meteorol., 2013, 32, doi:10.1155/2013/453521.

Nicholson, S. E. et al. (2003), Validation of TRMM and Other Rainfall Estimates with a High-Density Gauge Dataset for West Africa. Part I: Validation of GPCC Rainfall Product and Pre-TRMM Satellite and Blended Products, J. Appl. Meteorol., 42, 13371354, doi:10.1175/1520-0450(2003)042<1337:VOTAOR>2.0.CO;2.

Panthou, G., Vischel, T. and Lebel, T. (2014), Recent trends in the regime of extreme rainfall in the Central Sahel. Int. J. Climatol., 34: 3998-4006. doi:10.1002/joc.3984. 
Riahi, K., S. Rao, V. Krey, C. Cho, V. Chirkov, G. Fischer, G. Kindermann, N. Nakicenovic, and P. Rafaj (2011), RCP 8.5-A scenario of comparatively high greenhouse gas emissions, Clim. Change, 109, 33-57, doi:10.1007/s10584-011-0149-y.

Rodríguez-Fonseca, B. et al. (2015), Variability and Predictability of West African Droughts: A Review on the Role of Sea Surface Temperature Anomalies, J. Clim., 28, 4034-4060, doi:10.1175/JCLI-D-14-00130.1.

Roehrig, R., D. Bouniol, F. Guichard, F. D. Hourdin, and J. L. Redelsperger (2013), The present and future of the west african monsoon: A process-oriented assessment of CMIP5 simulations along the AMMA transect, J. Clim., 26, 6471-6505, doi:10.1175/JCLI-D-12-00505.1.

Rowell, D. P. (2001), Teleconnections between the tropical Pacific and the Sahel, Q. J. R. Meteorol. Soc., 127, 1683-1706, doi:10.1002/qj.49712757512.

Rowell, D. P. (2013), Simulating SST teleconnections to Africa: What is the state of the art?, J. Clim., 26, 5397-5418, doi:10.1175/JCLI-D-12-00761.1.

Santer, B. D. et al. (2009), Incorporating model quality information in climate change detection and attribution studies., Proc. Natl. Acad. Sci. U. S. A., 106, 14778-14783, doi:10.1073/pnas.0901736106.

Skinner, C. B., M. Ashfaq, and N. S. Diffenbaugh (2012), Influence of Twenty-First-Century Atmospheric and Sea Surface Temperature Forcing on West African Climate, J. Clim., 25, 527-542, doi:10.1175/2011JCLI4183.1.

Tanaka, H. L., N. Ishizaki, and A. Kitoh (2004), Trend and interannual variability of Walker, monsoon and Hadley circulations defined by velocity potential in the upper troposphere, Tellus, Ser. A Dyn. Meteorol. Oceanogr., 56, 250-269, doi:10.1111/j.16000870.2004.00049.x.

Taylor, K. E., R. J. Stouffer, and G. a. Meehl (2012), An overview of CMIP5 and the experiment design, Bull. Am. Meteorol. Soc., 93, 485-498, doi:10.1175/BAMS-D-1100094.1.

Thorncroft, C. D., and M. Blackburn (1999), Maintenance of the African easterly jet, Q. J. R. Meteorol. Soc., 125, 763-786, doi:10.1002/qj.49712555502.

Ting, M., Y. Kushnir, R. Seager, and C. Li (2009), Forced and Internal Twentieth-Century SST Trends in the North Atlantic, J. Clim., 22, 1469-1481, doi:10.1175/2008JCLI2561.1.

Trenberth, K.E., P.D. Jones, P. Ambenje, R. Bojariu, D. Easterling, A. Klein Tank, D. Parker, F. Rahimzadeh, J.A. Renwick, M. Rusticucci, B. Soden and P. Zhai, 2007: Observations: Surface and Atmospheric Climate Change. In: Climate Change 2007: The Physical Science Basis. Contribution of Working Group I to the Fourth Assessment Report of the Intergovernmental Panel on Climate Change [Solomon, S., D. Qin, M. Manning, Z. Chen, M. Marquis, K.B. Averyt, M. Tignor and H.L. Miller (eds.)]. Cambridge University Press, Cambridge, United Kingdom and New York, NY, USA.

Villamayor, J., and E. Mohino (2015), Robust Sahel drought due to the Interdecadal Pacific Oscillation in CMIP5 simulations, Geophys. Res. Lett., 42, 1214-1222, doi:10.1002/2014GL062473.

Vizy, E. K., and K. H. Cook (2009), A mechanism for African monsoon breaks: Mediterranean cold air surges, J. Geophys. Res. Atmos., 114, 1-19, doi:10.1029/2008JD010654. 
Xue, Y. et al. (2010), Intercomparison and analyses of the climatology of the West African Monsoon in the West African Monsoon Modeling and Evaluation project (WAMME) first model intercomparison experiment, Clim. Dyn., 35, 3-27, doi:10.1007/s00382-0100778-2.

Zhang, R., and T. L. Delworth (2006), Impact of Atlantic multidecadal oscillations on India/Sahel rainfall and Atlantic hurricanes, Geophys. Res. Lett., 33, L17712, doi:10.1029/2006GL026267. 
Table 1: Models analysed. CMIP5 model information and outputs are available through the

777 Earth System Grid Federation archive (http://cmip-pcmdi.llnl.gov/cmip5).

\begin{tabular}{|c|c|c|c|}
\hline Country & Modelling centre & Model & Resolution (lat-lon) \\
\hline China & $\begin{array}{l}\text { Beijing Climate Center, China } \\
\text { Meteorological Administration }\end{array}$ & BCC-CSM1-1 & $\mathrm{T} 42\left(\sim 2.8^{\circ}\right)$ \\
\hline Canada & $\begin{array}{l}\text { Canadian Centre for Climate Modelling } \\
\text { and Analysis }\end{array}$ & CanAM4 & $\mathrm{T} 42\left(\sim 2.8^{\circ}\right)$ \\
\hline USA & $\begin{array}{l}\text { National Centre for Atmospheric } \\
\text { Research }\end{array}$ & CCSM4 & $1.25^{\circ} \times 0.9^{\circ}$ \\
\hline France & $\begin{array}{l}\text { Centre National de Recherches } \\
\text { Météorologiques / Centre Européen de } \\
\text { Recherche et Formation Avancée en } \\
\text { Calcul Scientifique }\end{array}$ & CNRM-CM5 & $\mathrm{T} 127\left(\sim 1.4^{\circ}\right)$ \\
\hline China & $\begin{array}{l}\text { LASG, Institute of Atmospheric } \\
\text { Physics, Chinese Academy of Sciences } \\
\text { and CESS, Tsinghua University }\end{array}$ & FGOALS-g2 & $3.0^{\circ} \times 2.8^{\circ}$ \\
\hline $\begin{array}{l}\text { United } \\
\text { Kingdom }\end{array}$ & Met Office Hadley Centre & HadGEM2-A & $1.25^{\circ} \times 1.875^{\circ}$ \\
\hline \multirow[t]{2}{*}{ France } & \multirow[t]{2}{*}{ Institut Pierre-Simon Laplace } & IPSL-CM5A-LR & $1.875^{\circ} \times 3.75^{\circ}$ \\
\hline & & IPSL-CM5B-LR & $1.875^{\circ} \times 3.75^{\circ}$ \\
\hline Japan & $\begin{array}{l}\text { Atmosphere and Ocean Research } \\
\text { Institute (The University of Tokyo), } \\
\text { National Institute for Environmental } \\
\text { Studies, and Japan Agency for Marine- } \\
\text { Earth Science and Technology }\end{array}$ & MIROC5 & $\mathrm{T} 127\left(\sim 1.4^{\circ}\right)$ \\
\hline \multirow[t]{2}{*}{ Germany } & \multirow{2}{*}{$\begin{array}{l}\text { Max-Planck-Institut für Meteorologie } \\
\text { (Max Planck Institute for Meteorology) }\end{array}$} & MPI-ESM-LR & T63 $\left(\sim 1.9^{\circ}\right)$ \\
\hline & & MPI-ESM-MR & T63 $\left(\sim 1.9^{\circ}\right)$ \\
\hline Japan & Meteorological Research Institute & MRI-CGCM3 & $\mathrm{T} 159\left(\sim 1.125^{\circ}\right)$ \\
\hline
\end{tabular}


779 Table 2: Correlation coefficients between the 1979-2008 time series of the Z925-700

780 meridional gradient (GradZ) and the West African Monsoon Index (WAMI), and the

781 Sahelian rainfall index (SRI), in three experiments and in observations and reanalysis. The

782 linear trend has been removed from the time series. In bold, positive correlations significant

783 at $95 \%$ confidence level. The highest value between $4 \mathrm{~K}$ and $4 \mathrm{xCO} 2$ is underlined.

\begin{tabular}{|l|c|c|c|c|c|c|}
\hline \multirow{2}{*}{} & \multicolumn{3}{|c|}{ GradZ } & \multicolumn{3}{c|}{ WAMI } \\
\cline { 2 - 7 } & CTL & $4 \mathrm{~K}$ & 4 xCO2 & CTL & $4 \mathrm{~K}$ & 4 CO2 \\
\hline BCC-CSM1-1 & 0.07 & $\mathbf{0 . 3 8}$ & $\underline{\mathbf{0 . 6 3}}$ & 0.06 & -0.50 & $\underline{\mathbf{0 . 6 7}}$ \\
\hline CanAM4 & 0.29 & $\mathbf{0 . 4 8}$ & $\underline{\mathbf{0 . 6 4}}$ & 0.21 & 0.21 & $\underline{\mathbf{0 . 8 3}}$ \\
\hline CCSM4 & $\mathbf{0 . 4 5}$ & $\mathbf{0 . 5 7}$ & $\underline{\mathbf{0 . 6 6}}$ & $\mathbf{0 . 5 2}$ & $\mathbf{0 . 6 6}$ & $\underline{\mathbf{0 . 6 9}}$ \\
\hline CNRM-CM5 & $\mathbf{0 . 4 7}$ & 0.33 & $\underline{\mathbf{0 . 7 1}}$ & $\mathbf{0 . 3 7}$ & $\mathbf{0 . 3 8}$ & $\underline{\mathbf{0 . 5 8}}$ \\
\hline FGOALS-g2 & $\mathbf{0 . 3 8}$ & $\mathbf{0 . 6 0}$ & $\underline{\mathbf{0 . 7 0}}$ & -0.03 & -0.71 & $\underline{\mathbf{0 . 5 0}}$ \\
\hline HadGEM2-A & $\mathbf{0 . 6 8}$ & $\mathbf{0 . 5 4}$ & $\underline{\mathbf{0 . 8 1}}$ & $\mathbf{0 . 5 3}$ & 0.09 & $\underline{\mathbf{0 . 6 5}}$ \\
\hline IPSL-CM5A-LR & $\mathbf{0 . 4 3}$ & $\underline{\mathbf{0 . 5 4}}$ & 0.20 & $\mathbf{0 . 4 8}$ & $\underline{\mathbf{0 . 3 8}}$ & 0.25 \\
\hline IPSL-CM5B-LR & -0.20 & $\underline{0.23}$ & 0.15 & -0.03 & -0.71 & $\underline{\mathbf{0 . 5 0}}$ \\
\hline MIROC5 & 0.30 & $\underline{\mathbf{0 . 7 8}}$ & $\mathbf{0 . 5 7}$ & $\mathbf{0 . 5 0}$ & $\underline{\mathbf{0 . 6 9}}$ & $\mathbf{0 . 6 0}$ \\
\hline MPI-ESM-LR & $\mathbf{0 . 3 9}$ & $\mathbf{0 . 4 0}$ & $\underline{\mathbf{0 . 7 1}}$ & $\mathbf{0 . 5 4}$ & 0.08 & $\underline{\mathbf{0 . 7 6}}$ \\
\hline MPI-ESM-MR & $\mathbf{0 . 5 9}$ & 0.06 & $\underline{\mathbf{0 . 6 6}}$ & $\mathbf{0 . 5 6}$ & -0.22 & $\underline{\mathbf{0 . 5 4}}$ \\
\hline MRI-CGCM3 & $\mathbf{0 . 6 9}$ & $\mathbf{0 . 4 4}$ & $\underline{\mathbf{0 . 5 8}}$ & 0.20 & 0.24 & $\underline{\mathbf{0 . 4 1}}$ \\
\hline MMM & $\mathbf{0 . 5 5}$ & $\mathbf{0 . 5 2}$ & $\underline{\mathbf{0 . 7 3}}$ & $\mathbf{0 . 4 6}$ & 0.34 & $\underline{\mathbf{0 . 6 1}}$ \\
\hline ERAI, GPCP & $\mathbf{0 . 7 5}$ & & & $\mathbf{0 . 7 7}$ & & \\
\hline
\end{tabular}


a) GPCP precipitation [mm/day]

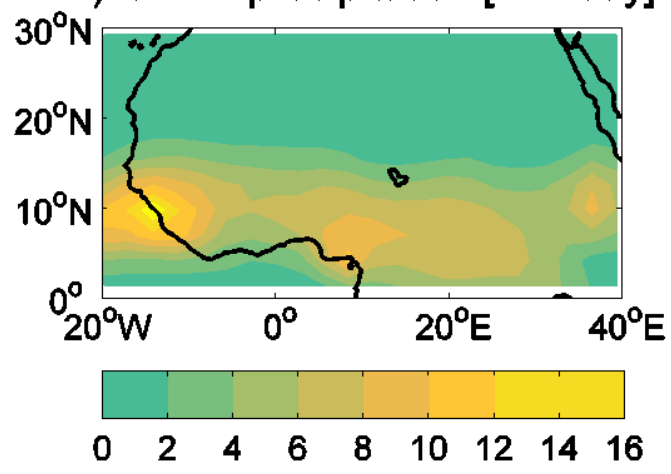

c) CTL-GPCP

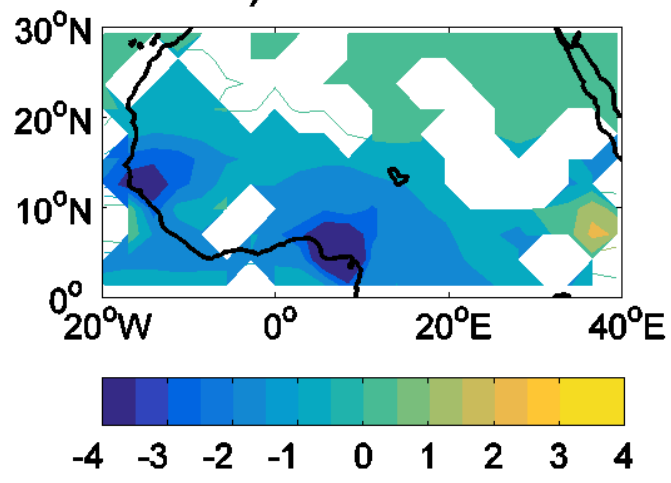

b) CTL precipitation [mm/day]

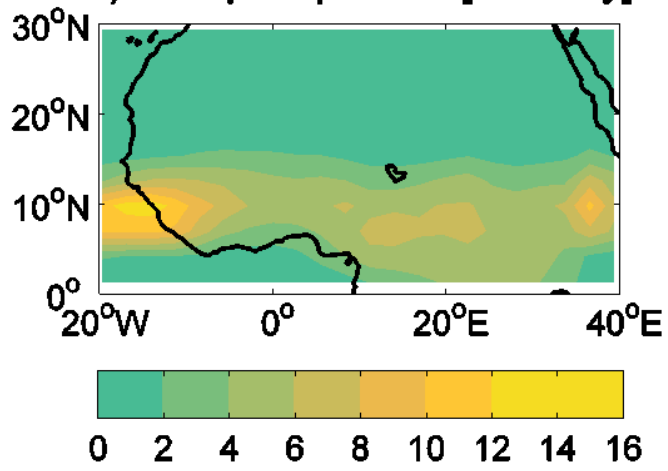

d) $4 \mathrm{~K}-\mathrm{CTL}$

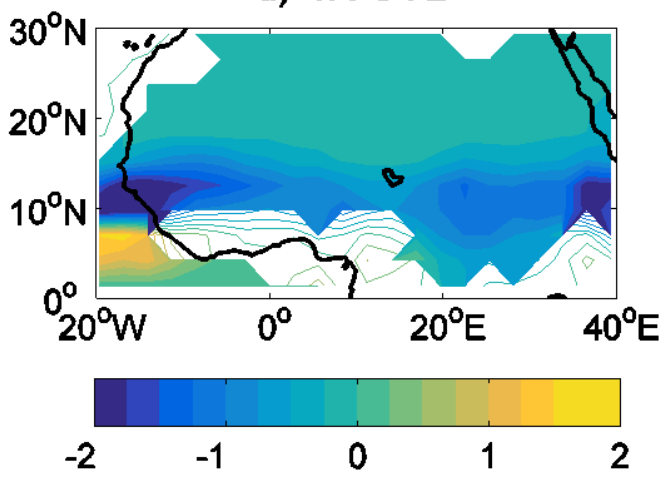

e) $4 \times C O 2-C T L$

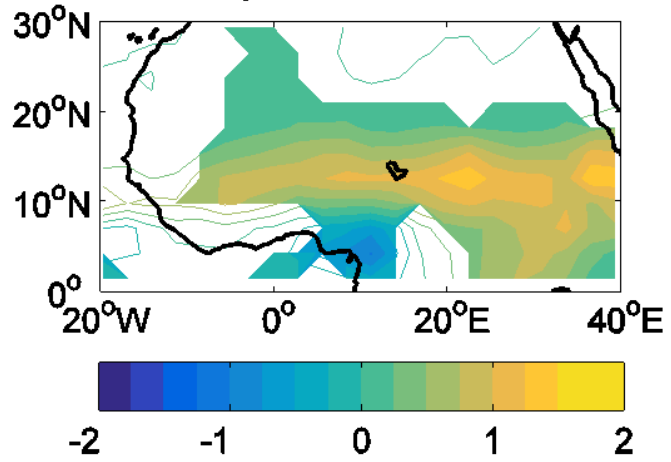

787 Figure 1: JAS precipitation [mm/day]: (a) GPCP observations, (b) MMM of the CTL

788 simulation and (c) difference with observations, and MMM differences between (d) $4 \mathrm{~K}$ and (e) $4 \times \mathrm{xCO} 2$ experiments and CTL simulation. Significant differences at 95\% confidence level are shaded. Note that the reference scale is not the same for the climatology, the model bias, and the sensitivity experiment responses. 
a) Sahel precipitation differences

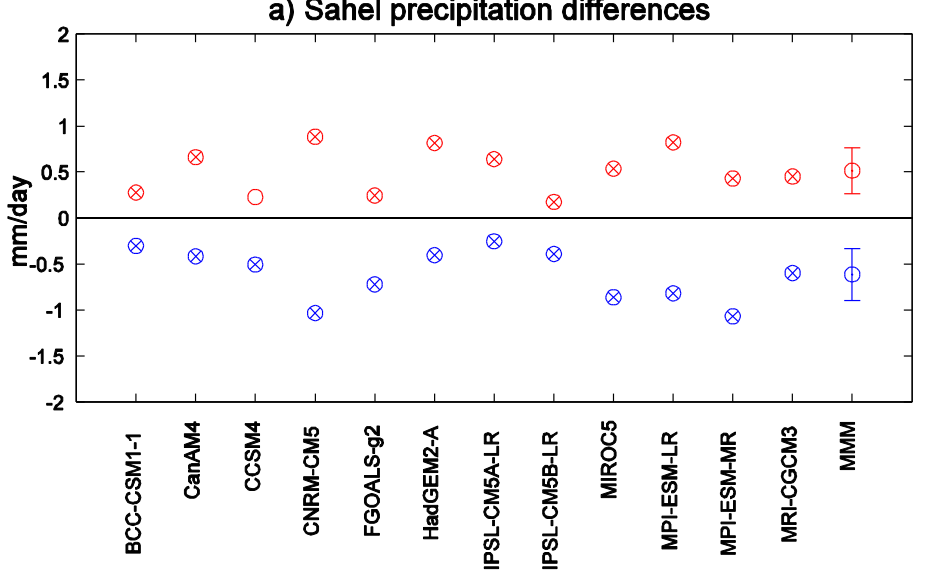

b) West Sahel precipitation differences

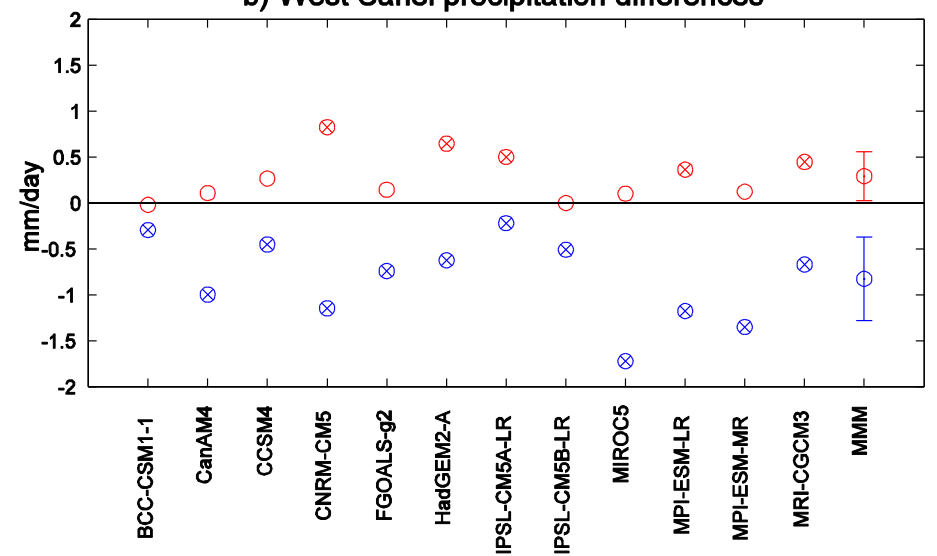

c) East Sahel precipitation differences

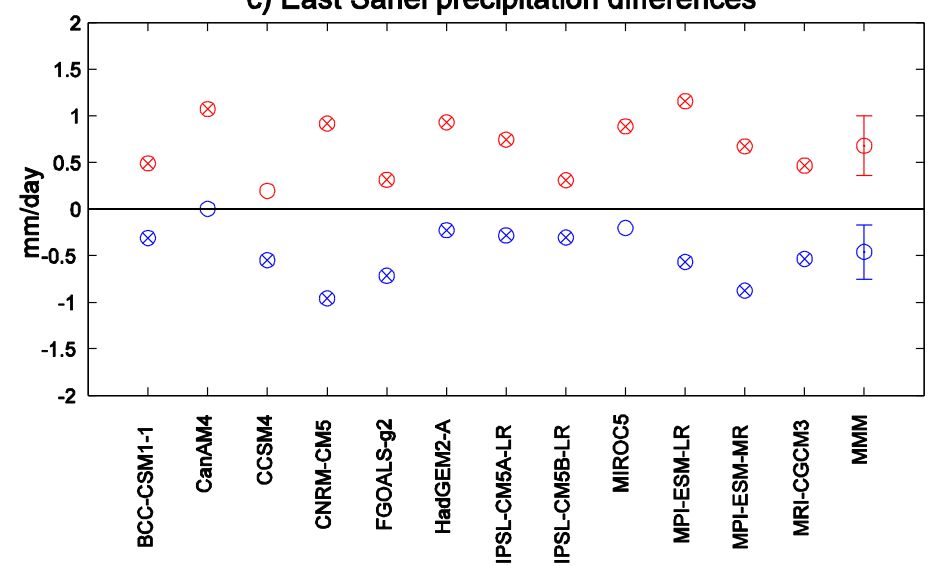

793 Figure 2: JAS precipitation [mm/day]: differences between the $4 \mathrm{~K}$ (blue circles) and 4xCO2

794 (red circles) experiments and the CTL simulation, in (a) Sahel $\left[10^{\circ}-20^{\circ} \mathrm{N}, 20^{\circ} \mathrm{W}-30^{\circ} \mathrm{E}\right]$, (b)

795 western (west of $0^{\circ} \mathrm{E}$ ) and (c) eastern Sahel (east of $0^{\circ} \mathrm{E}$ ). Vertical bars for the MMM indicate

796 multi-model STD, crosses indicate significant differences at 95\% confidence level. 
a) Precipitation $[\mathrm{mm} / \mathrm{day}]:(4 \mathrm{~K}-\mathrm{CTL})+(4 \times \mathrm{CO} 2-\mathrm{CTL})$

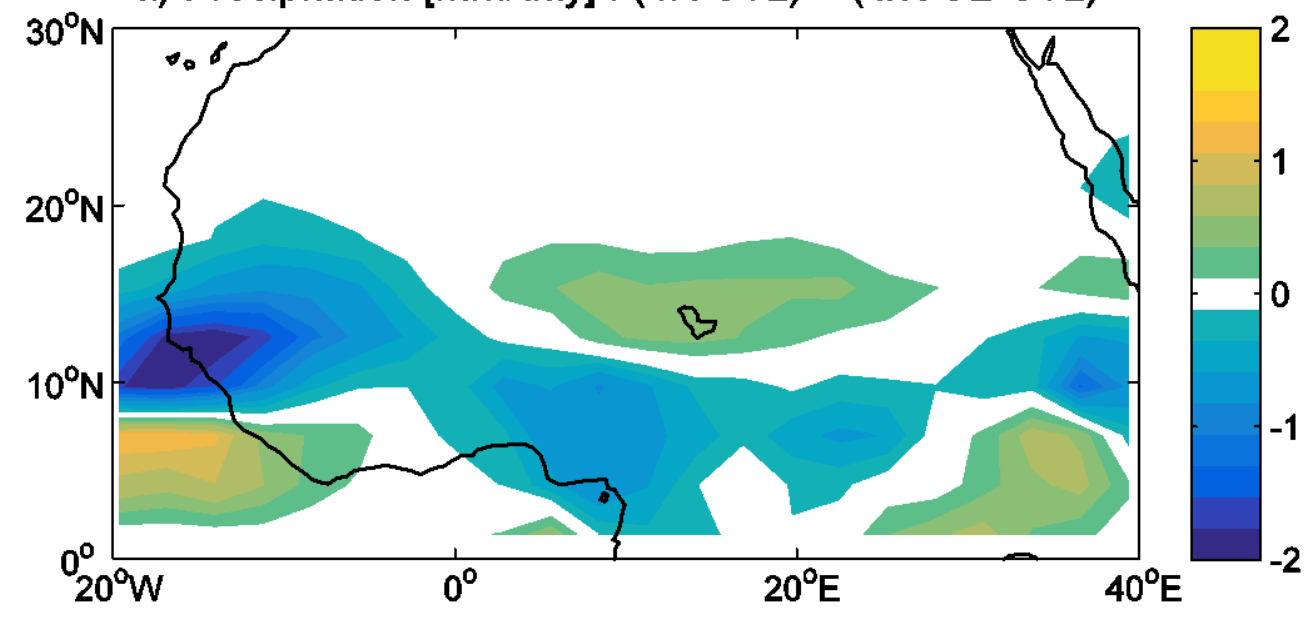

b) Precipitation [mm/day] : 2100 minus 2006 in RCP8.5

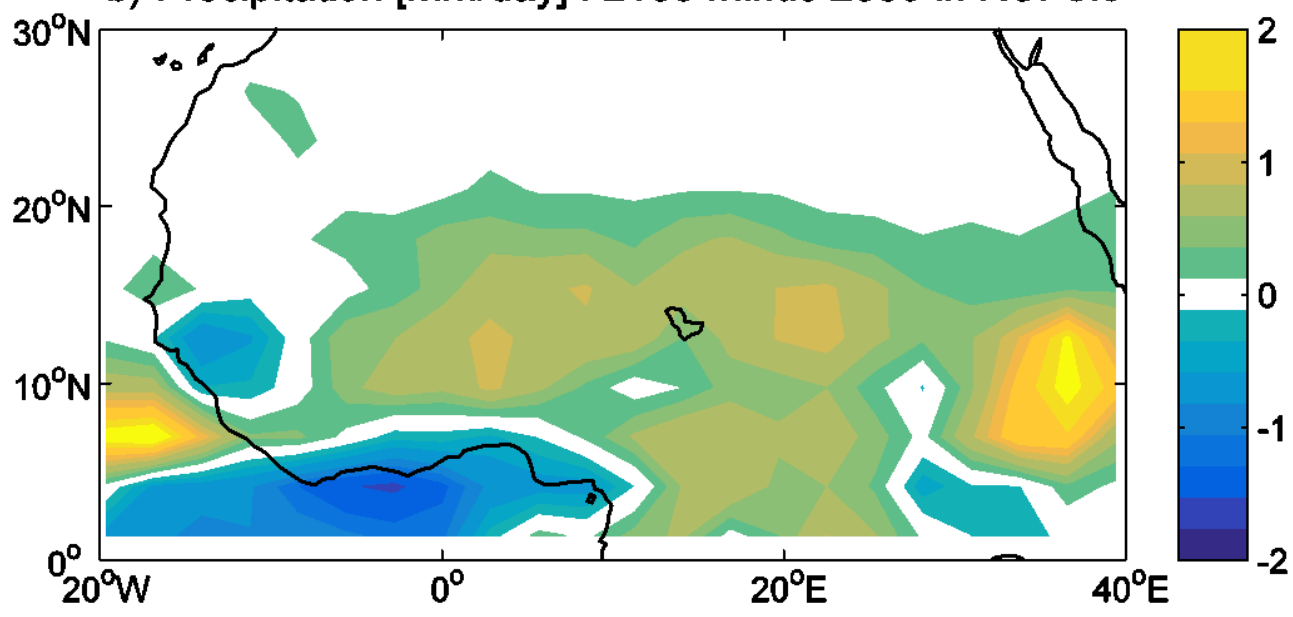

799 Figure 3: MMM of the JAS precipitation [mm/day]: (a) combination of the differences 800 between $4 \mathrm{~K}$ and $4 \mathrm{xCO} 2$ experiments and CTL simulation, computed as the sum of the 801 responses displayed in Figure 1; and (b) 21st century changes in the RCP8.5 scenario, 802 computed as the year 2100 minus 2006 difference assuming a linear trend over the period $803 \quad 2006-2100$. 
a) CTL $925 \mathrm{hPa}$ horizontal wind
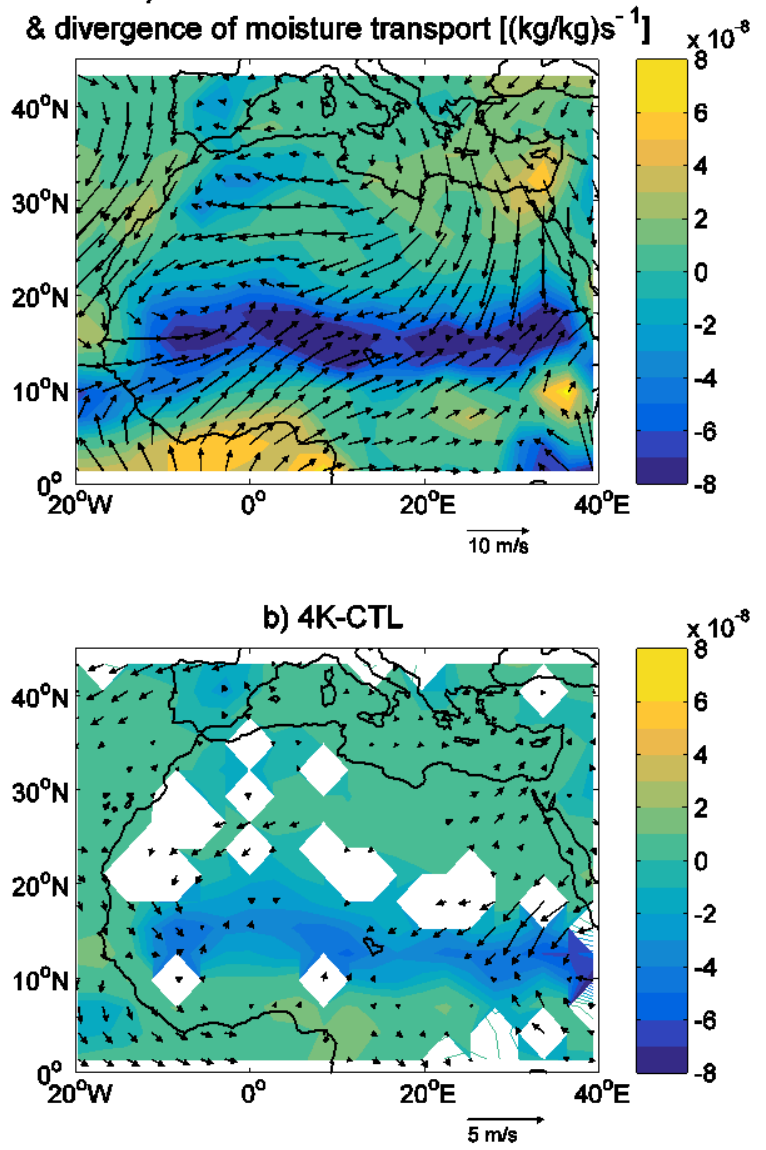

c) $4 \times C O 2-C T L$

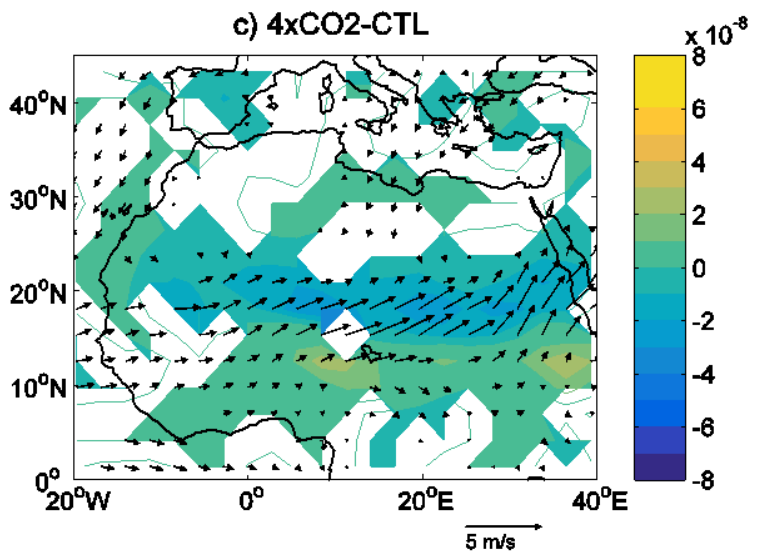

806 Figure 4: JAS horizontal wind (vectors) and moisture transport divergence (contour and

807 shadings) at $925 \mathrm{hPa}\left[\mathrm{kg} / \mathrm{kg}^{*} \mathrm{~s}^{-1}\right]$ : (a) MMM of the CTL simulation and MMM differences

808 between (b) $4 \mathrm{~K}$ and (c) 4xCO2 experiments and CTL simulation. Vectors and shadings

809 indicate differences significant at $95 \%$ confidence level. Note that the reference vector is not

810 the same for the CTL simulation and the sensitivity experiment responses. 
a) CTL TOA Radiative Balance $\left[\mathrm{W} / \mathrm{m}^{2}\right]$

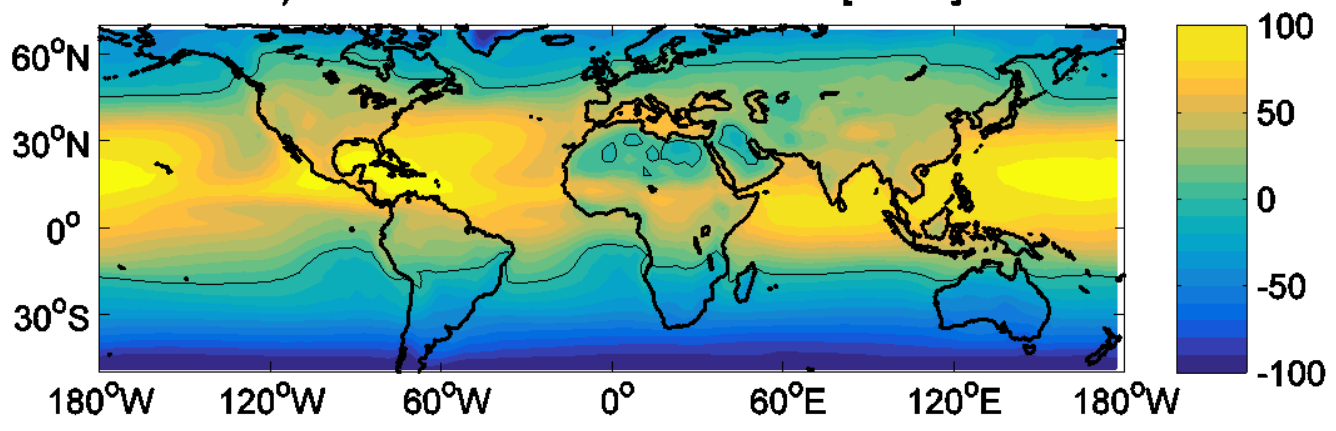

b) $4 \mathrm{~K}-\mathrm{CTL}$

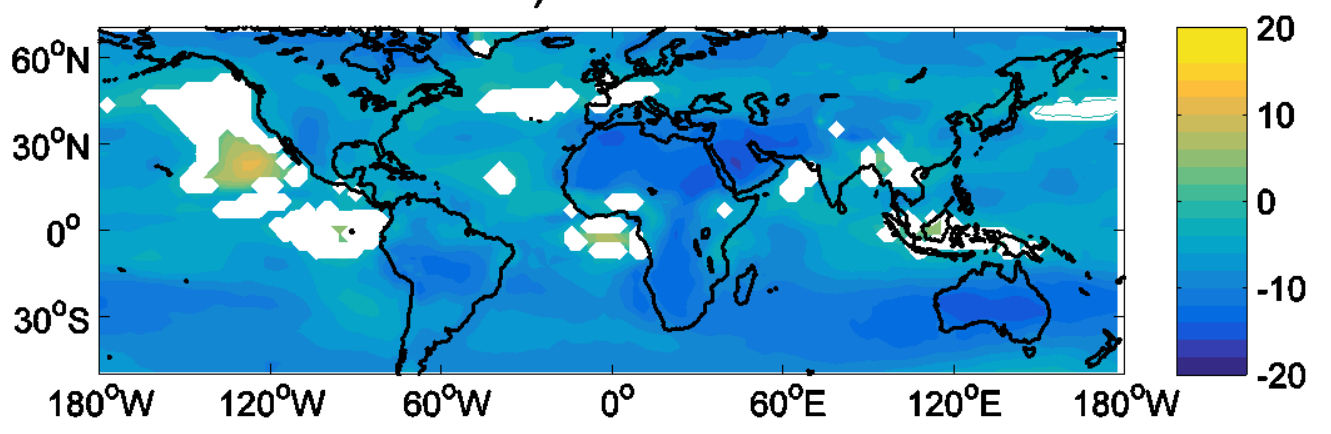

c) $4 \times C O 2-C T L$

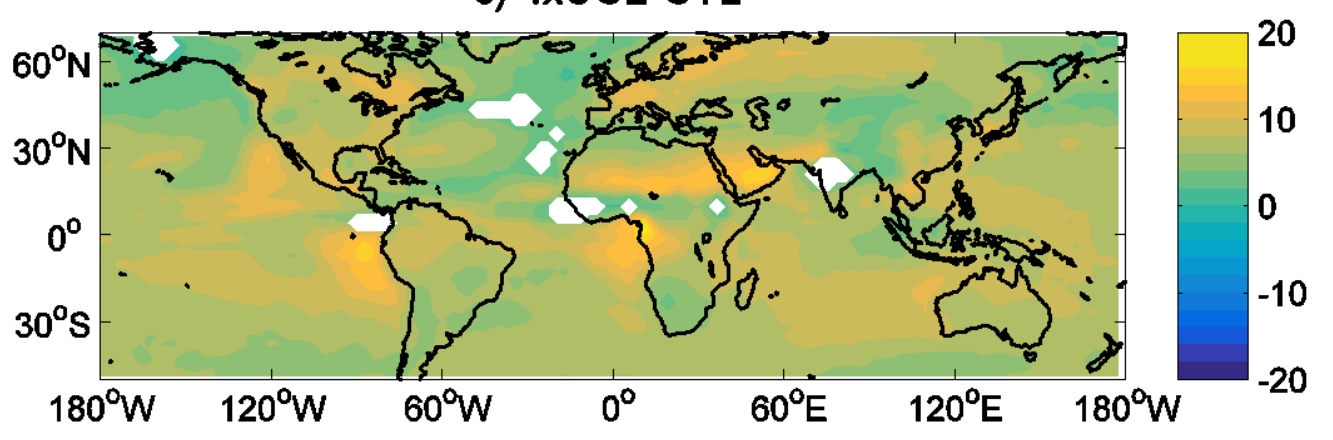

812 Figure 5: JAS global net radiative balance, defined at the top of the atmosphere as the

813 difference between the downward shortwave radiation and the sum of upward shortwave and 814 longwave radiation: (a) MMM of the CTL simulation and MMM differences between (b) 4K 815 and (c) 4xCO2 experiments and CTL simulation. In panel (a), black contours highlight the 816 separation between positive and negative values. Significant differences at $95 \%$ confidence

817 level are shaded. Note that the reference scale is not the same for the CTL simulation and the 818 sensitivity experiment responses. 
a) CTL MSE925-700 [J/kg]

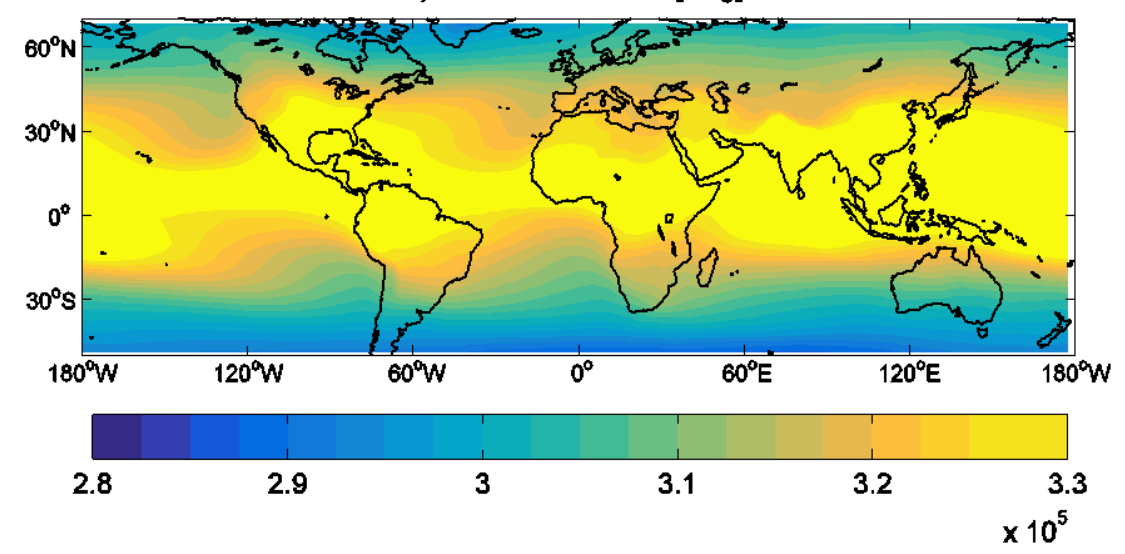

c) $4 \mathrm{~K}-\mathrm{CTL}$

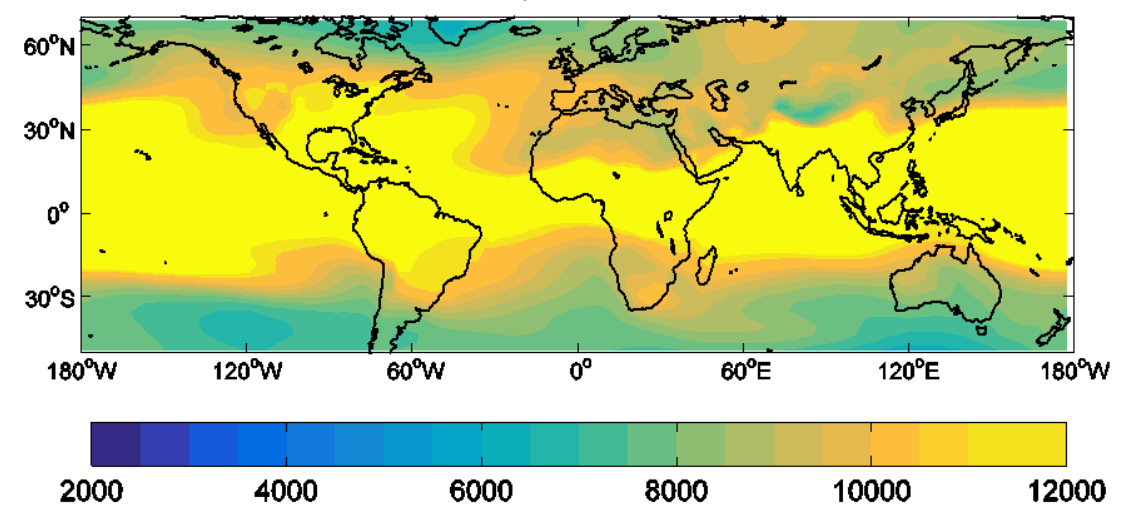

e) $4 \mathrm{xCO} 2-\mathrm{CTL}$

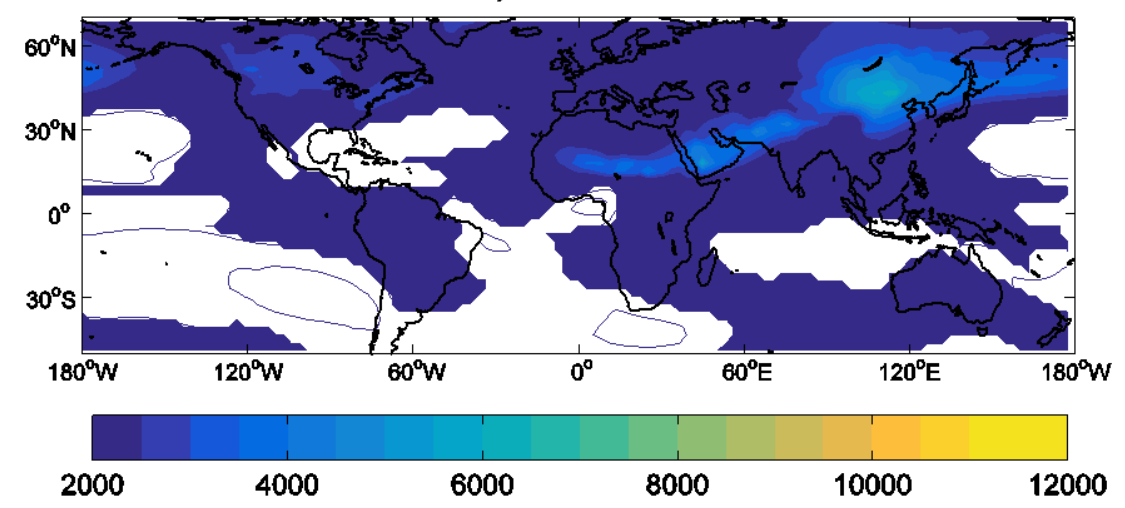

821 Figure 6: JAS (left) MSE and (right) DSE integrated in the 925-700 hPa layer: (top) MMM of

822 the CTL simulation and MMM differences between (middle) $4 \mathrm{~K}$ and (bottom) 4xCO2

823 experiments and CTL simulation. Significant differences at 95\% confidence level are shaded.

824 Note that the reference scale is not the same for the CTL simulation and the sensitivity

825 experiment responses. 
b) CTL DSE925-700 [J/kg]

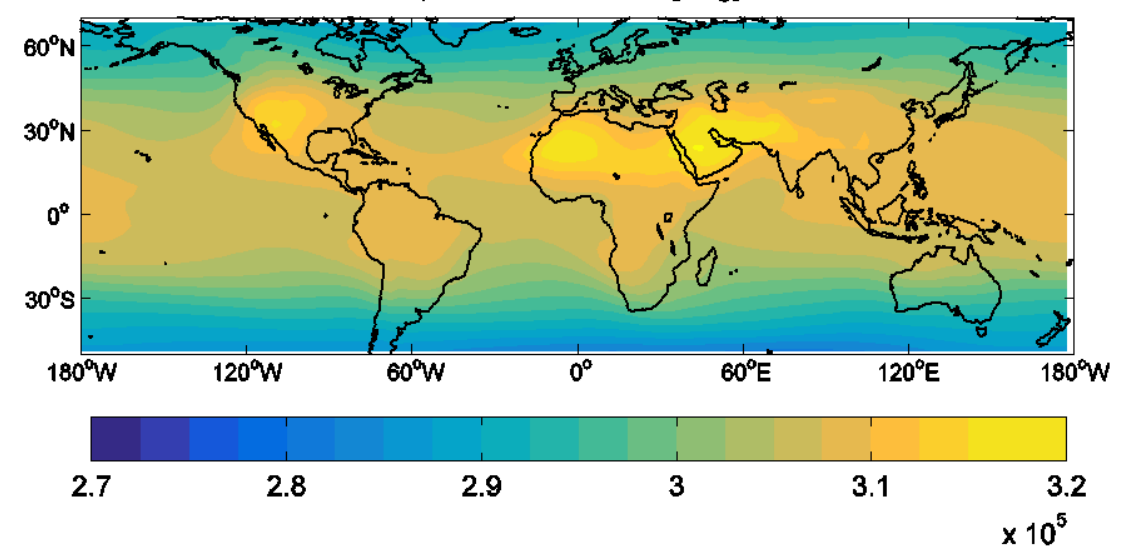

d) $4 \mathrm{~K}-\mathrm{CTL}$
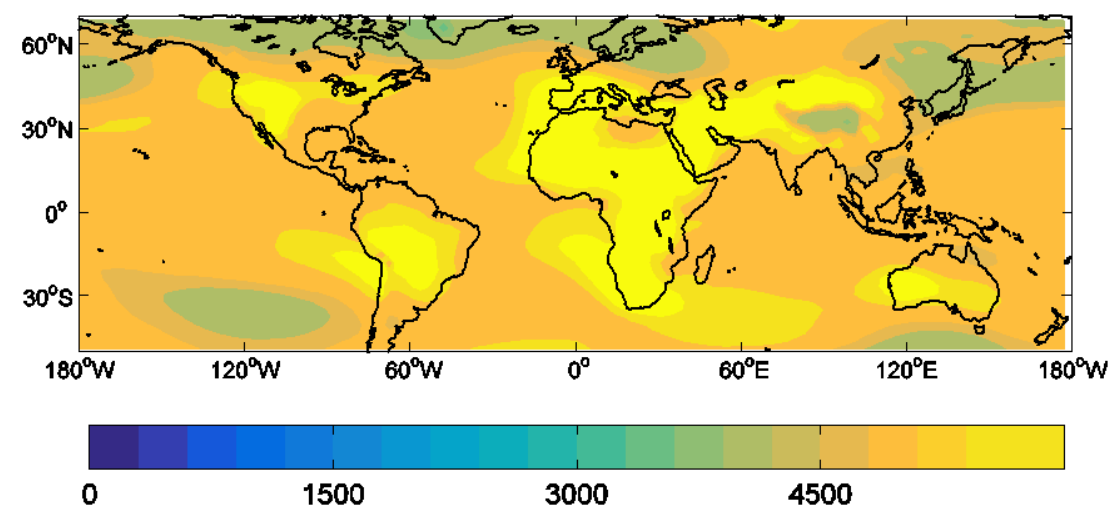

f) $4 \times \mathrm{CO} 2-\mathrm{CTL}$

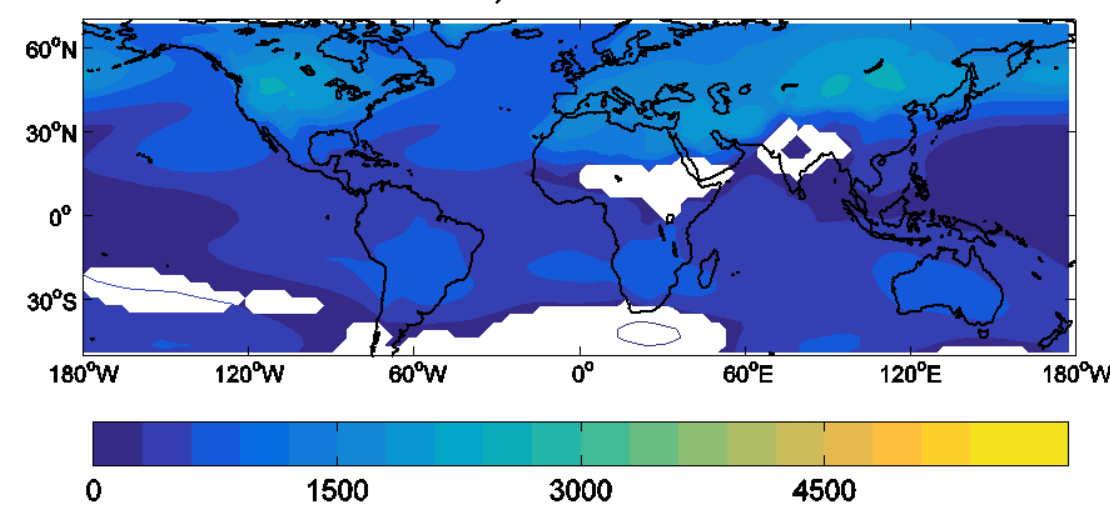

826

827 Figure 6: Continued. 
a) CTL meridional circulation $10^{\circ} \mathrm{W}-10^{\circ} \mathrm{E}$

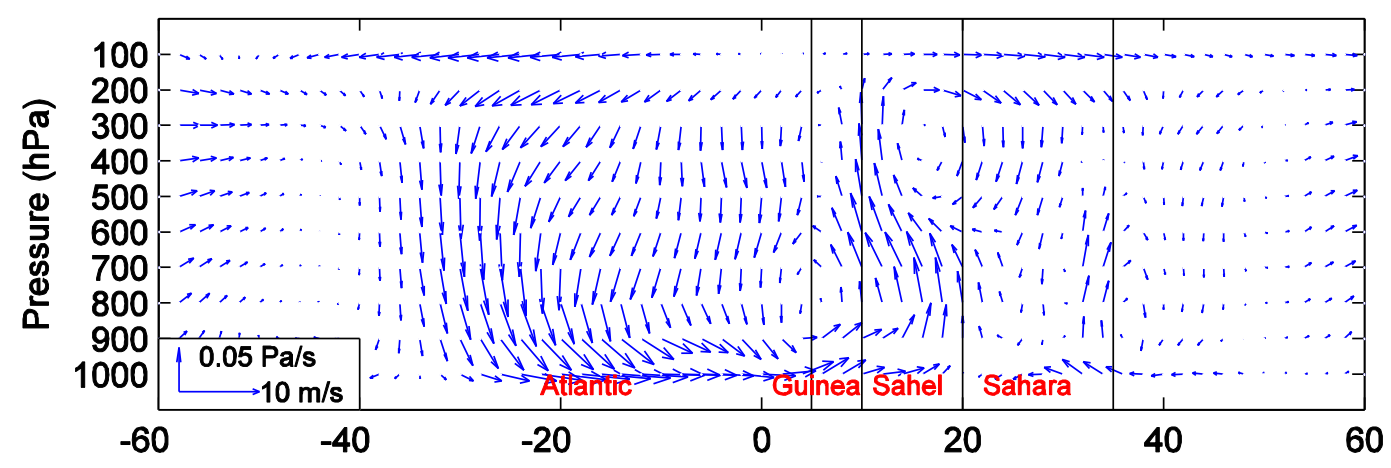

b) $4 \mathrm{~K}-\mathrm{CTL}$

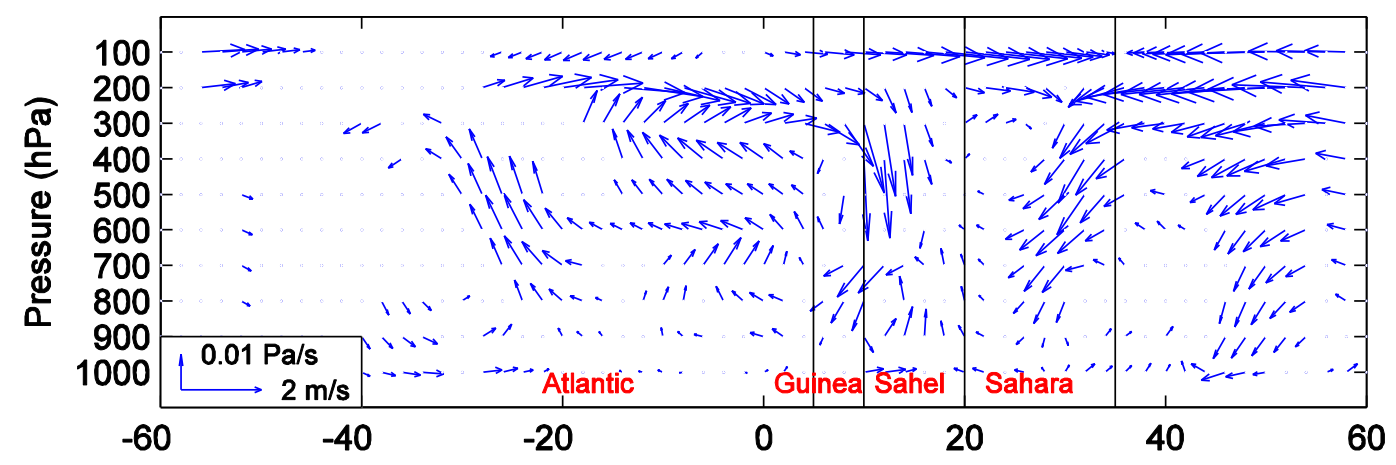

c) $4 \times C O 2-C T L$

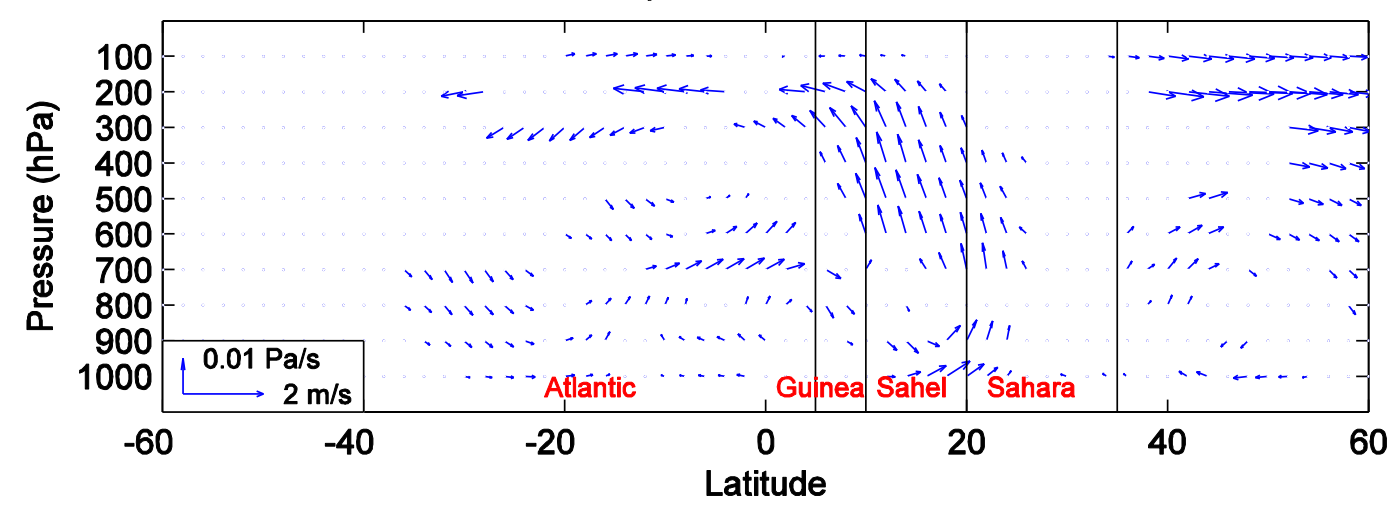

830 Figure 7: JAS meridional circulation averaged in $\left[10^{\circ} \mathrm{W}, 10^{\circ} \mathrm{E}\right]$, displayed through meridional

831 wind $[\mathrm{m} / \mathrm{s}]$ and vertical velocity $[\mathrm{Pa} / \mathrm{s}]$ vectors in latitude-pressure plots. (a) MMM of the

832 CTL simulation and MMM differences between (b) 4K and (c) 4xCO2 experiments and CTL

833 simulations. Significant differences at $95 \%$ confidence level are displayed. Note that the 834 reference vectors are not the same for the CTL simulation and the sensitivity experiment 835 responses. 


\section{a) CTL zonal circulation $5^{\circ} \mathrm{N}-20^{\circ} \mathrm{N}$}

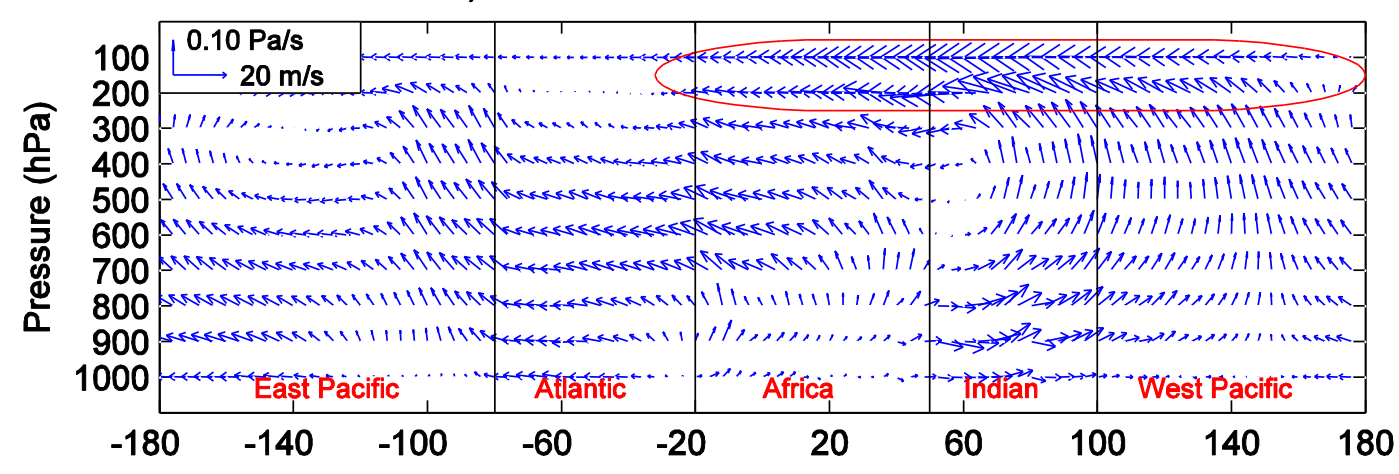

b) $4 \mathrm{~K}-\mathrm{CTL}$

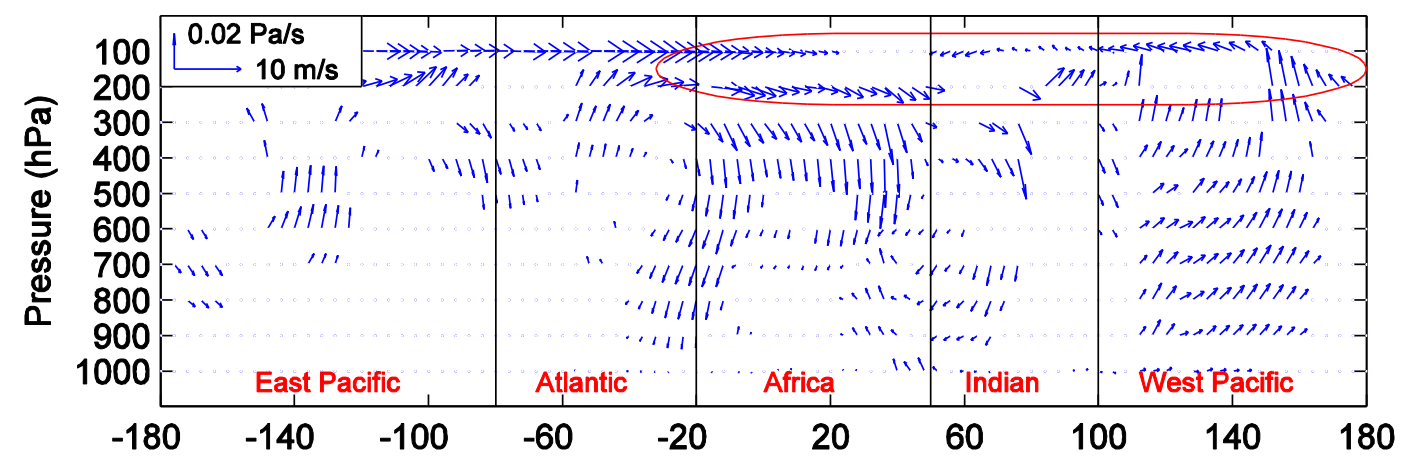

c) $4 \times C O 2-C T L$

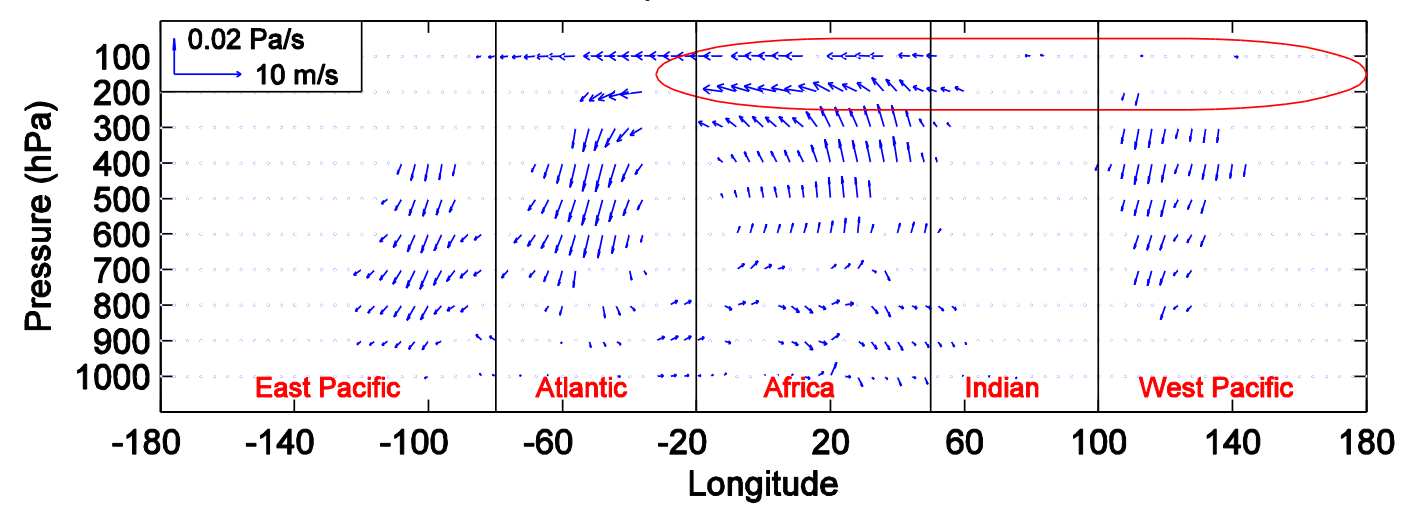

838 Figure 8: JAS zonal circulation averaged in $\left[5^{\circ} \mathrm{N}, 20^{\circ} \mathrm{N}\right]$, displayed through zonal wind $[\mathrm{m} / \mathrm{s}]$ and vertical velocity $[\mathrm{Pa} / \mathrm{s}]$ vectors in latitude-pressure plots. (a) MMM of the CTL

840 simulation and MMM differences between (b) $4 \mathrm{~K}$ and (c) 4xCO2 experiments and CTL

841 simulation. The TEJ region in the upper troposphere is highlighted in red. Significant

842 differences at $95 \%$ confidence level are displayed. Note that the reference vectors are not the 843 same for the CTL simulation and the sensitivity experiment responses. 
a) CTL velocity potential $\left[\mathrm{m}^{2} / \mathrm{s}\right]$

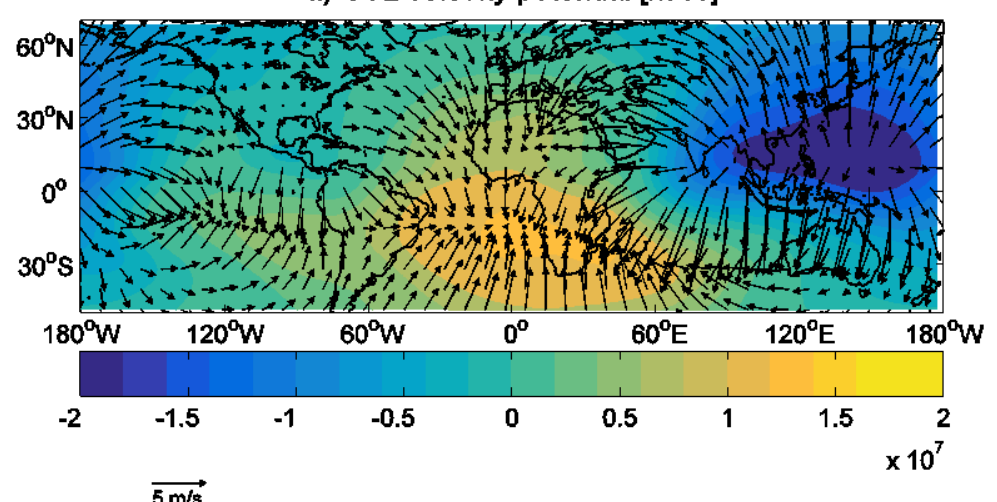

b) $4 \mathrm{~K}-\mathrm{CTL}$

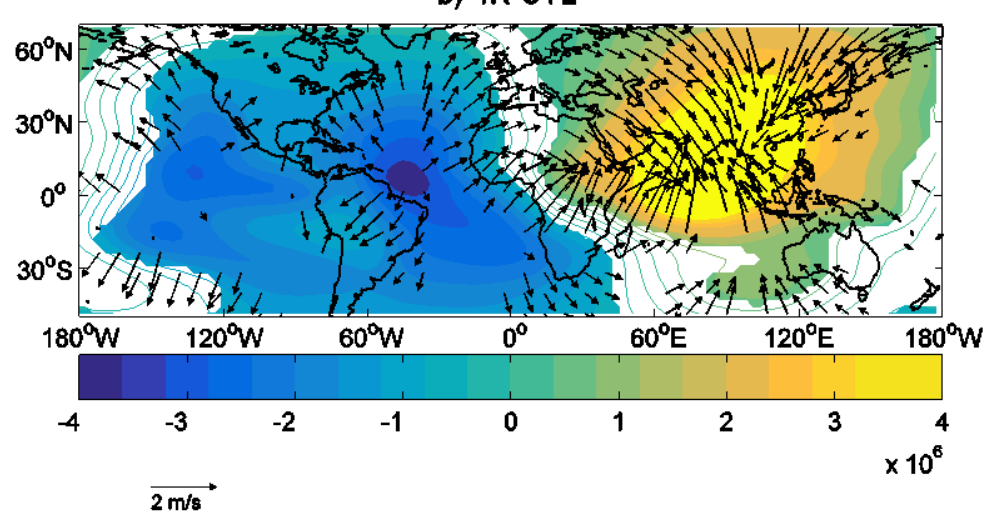

c) $4 \times \mathrm{CO} 2-\mathrm{CTL}$

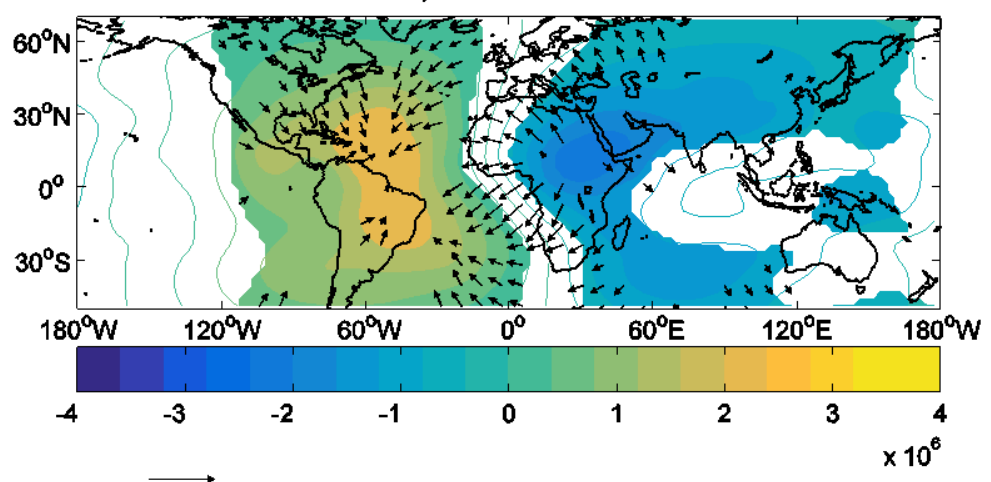

$\overrightarrow{2 m / s}$

846 Figure 9: JAS velocity potential $\left[\mathrm{m}^{2} / \mathrm{s}\right]$ (contours and shadings) and divergent wind (vectors)

847 at $200 \mathrm{hPa}$ : (a) MMM of the CTL simulation and MMM differences between (b) $4 \mathrm{~K}$ and (c)

$8484 \mathrm{xCO} 2$ experiments and CTL simulation. Divergent wind is computed as the gradient of the

849 velocity potential. Vectors and shadings indicate differences significant at $95 \%$ confidence

850 level. Note that reference scales and vectors are not the same for the CTL simulation and the

851 sensitivity experiment responses. 

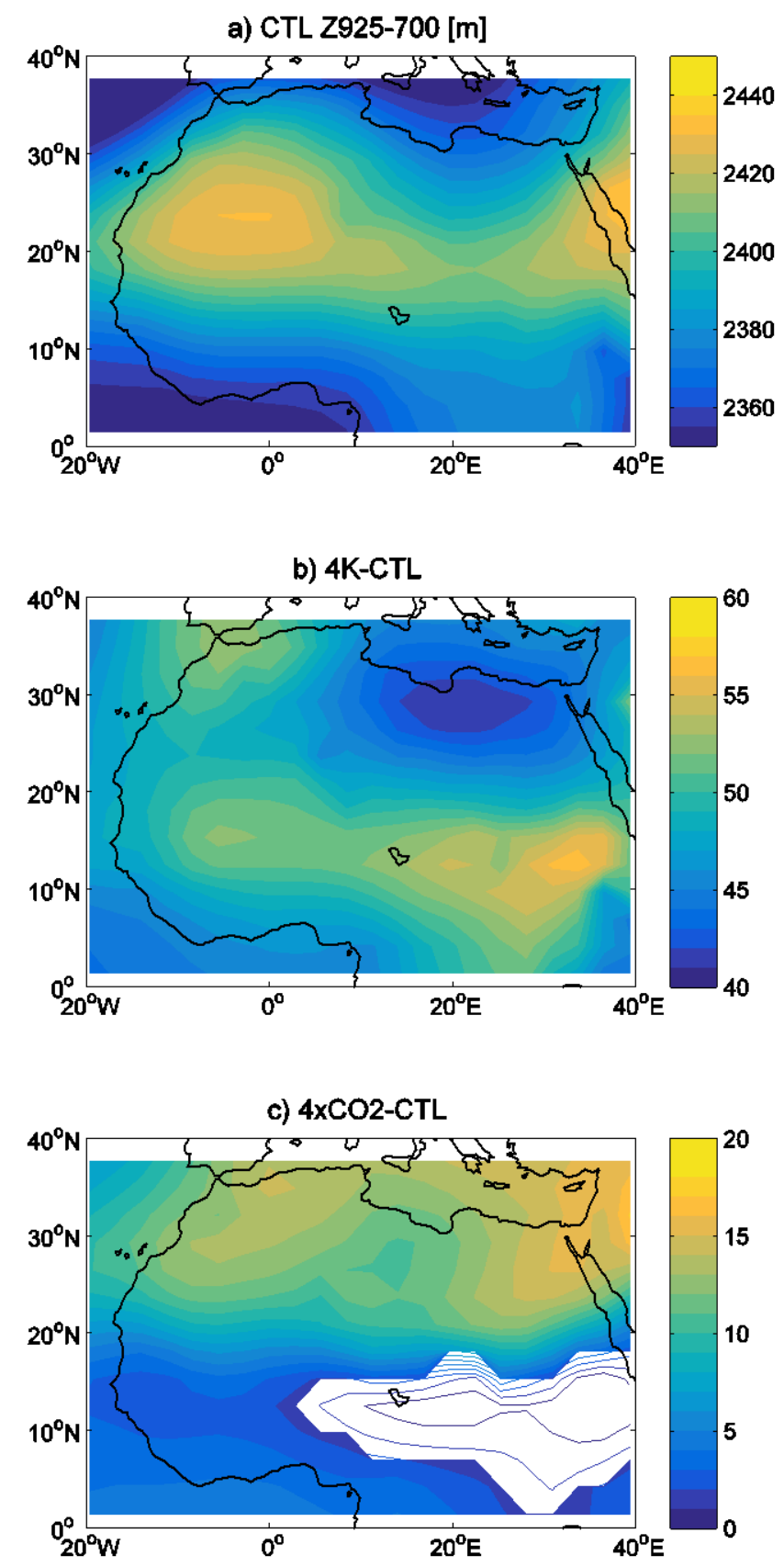

853 Figure 10: JAS 925-700 hPa thickness [m], defined as the difference in geopotential height 854 between 700 and 925 hPa: (a) MMM of the CTL simulation and MMM differences between 855 (b) $4 \mathrm{~K}$ and (c) 4xCO2 experiments and CTL simulation. Significant differences at 95\% 856 confidence level are shaded. Note that the reference scale is not the same for the CTL 857 simulation and the sensitivity experiment responses. 

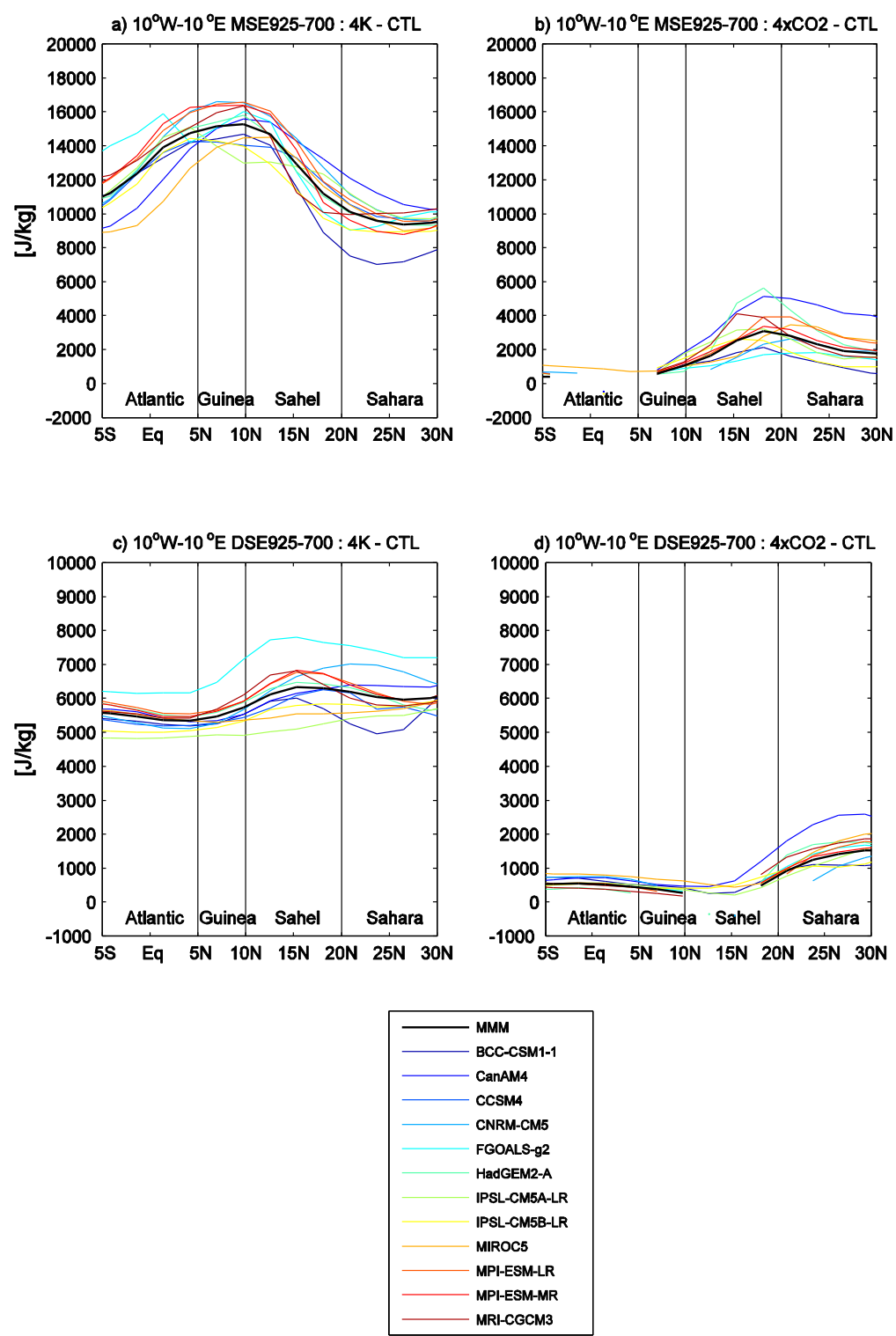

859 Figure 11: JAS meridional profile of (top) MSE and (bottom) DSE, integrated in the 925-700

$860 \mathrm{hPa}$ layer $[\mathrm{J} / \mathrm{kg}]$ and averaged over West Africa $\left[10^{\circ} \mathrm{W}-10^{\circ} \mathrm{E}\right]$ : (left) $4 \mathrm{~K}$ and (right) $4 \mathrm{xCO} 2$

861 differences with CTL simulation. Significant differences at 95\% confidence level are

862 displayed. Note the differences in the y-axis values. 


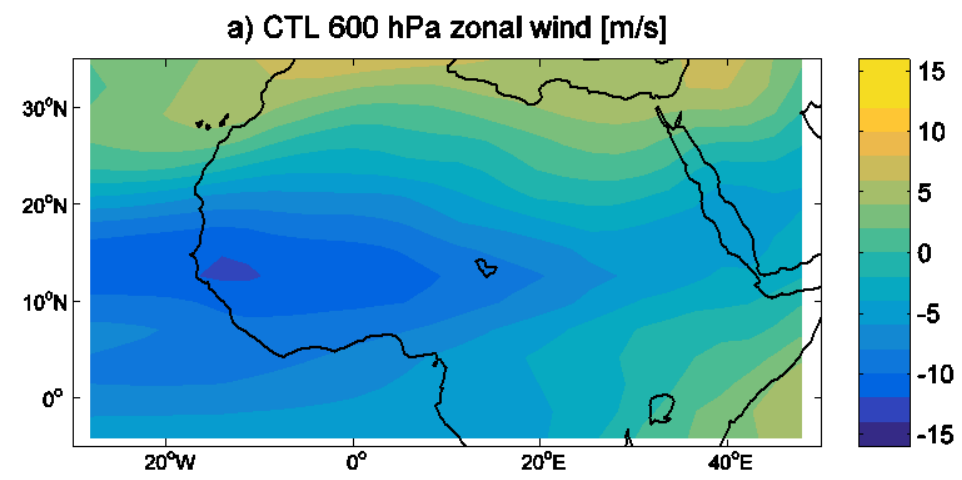

b) $4 \mathrm{~K}-\mathrm{CTL}$

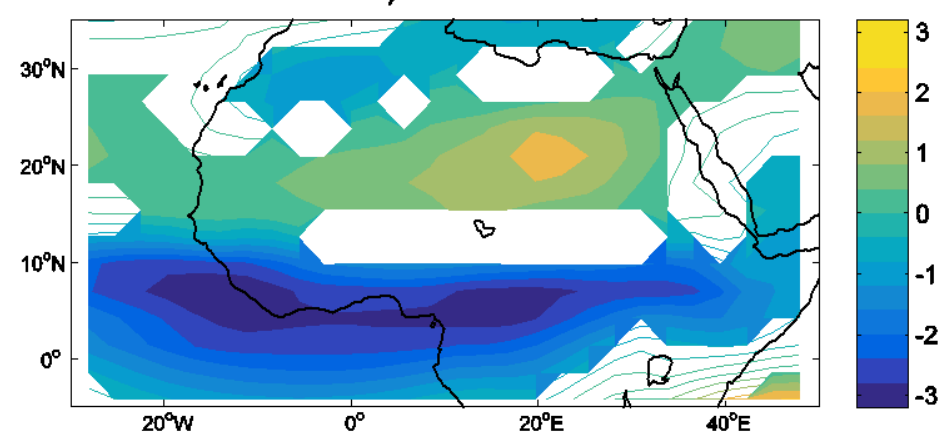

c) $4 \times C O 2-C T L$

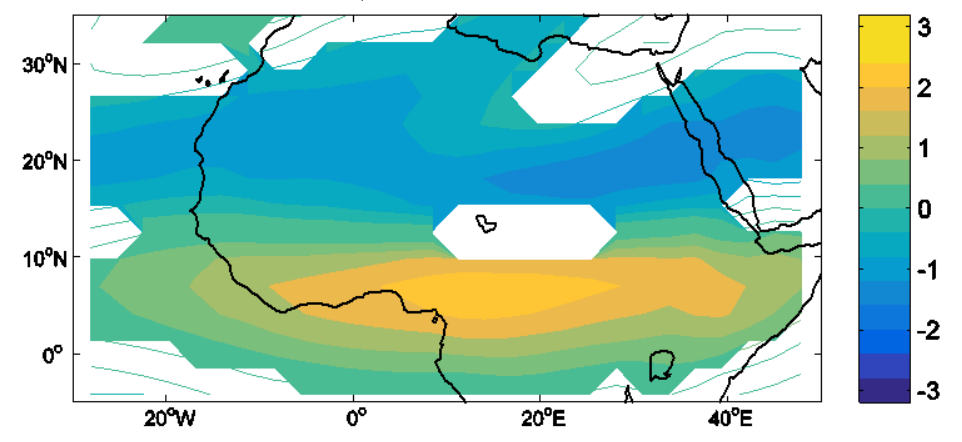

865 Figure 12: JAS zonal wind at $600 \mathrm{hPa}$ [m]: (a) MMM of the CTL simulation and MMM

866 differences between (b) $4 \mathrm{~K}$ and (c) $4 \mathrm{xCO} 2$ experiments and CTL simulation. Significant

867 differences at $95 \%$ confidence level are shaded. Note that the reference scale is not the same

868 for the CTL simulation and the sensitivity experiment responses. 


\section{a) CTL correlation SRI vs $600 \mathrm{hPa}$ zonal wind}

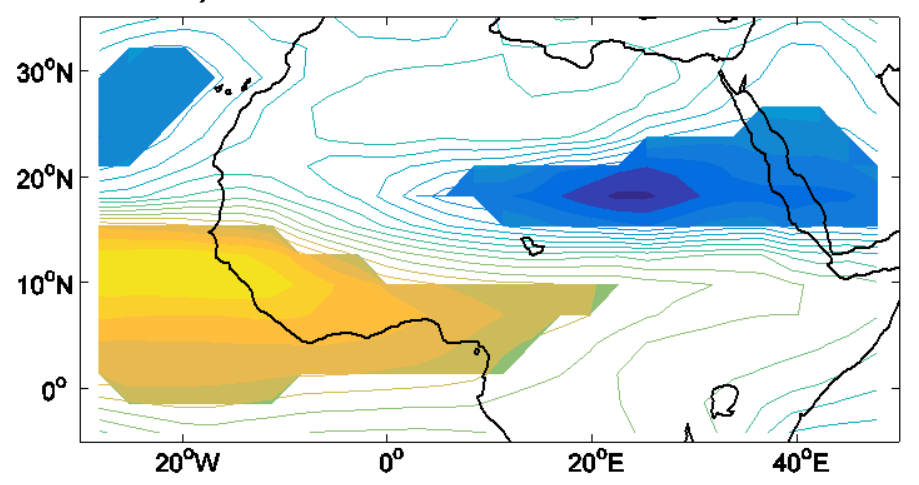

b) $4 \mathrm{~K}$

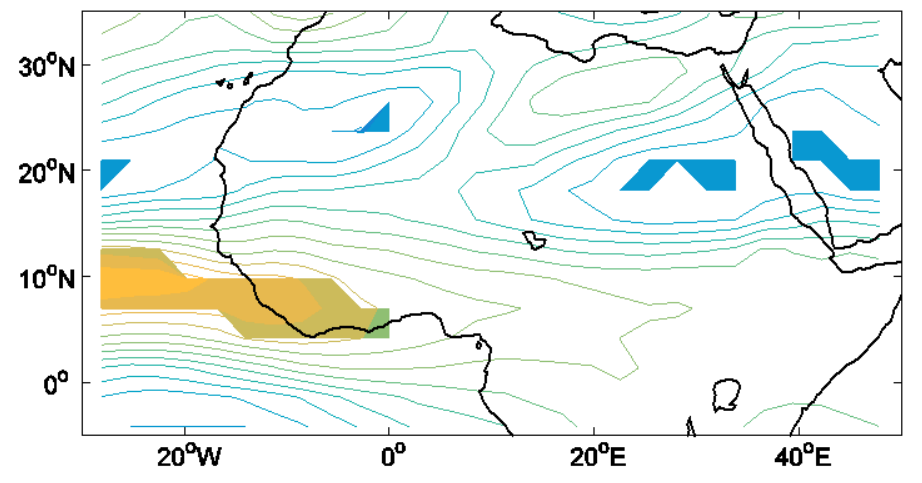

c) $4 \times \mathrm{CO} 2$

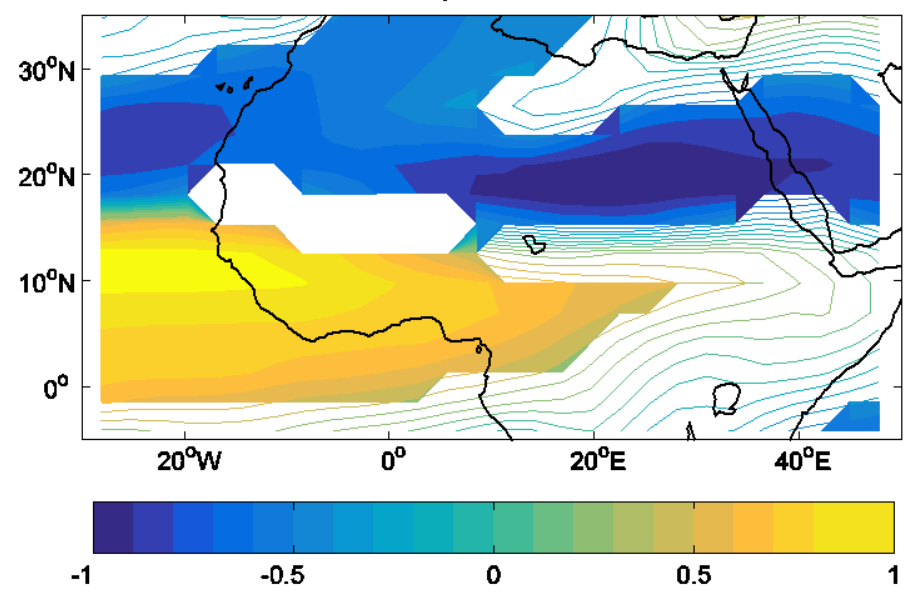

871 Figure 13: Correlation between the JAS MMM of SRI and zonal wind at $600 \mathrm{hPa}$ for the

872 period 1979-2008: a) CTL simulation, b) 4K and c) 4xCO2 experiments. Correlations

873 significant at $95 \%$ confidence level are shaded. The linear trend has been removed from the

874 SRI time series and the zonal wind at each grid-point. 

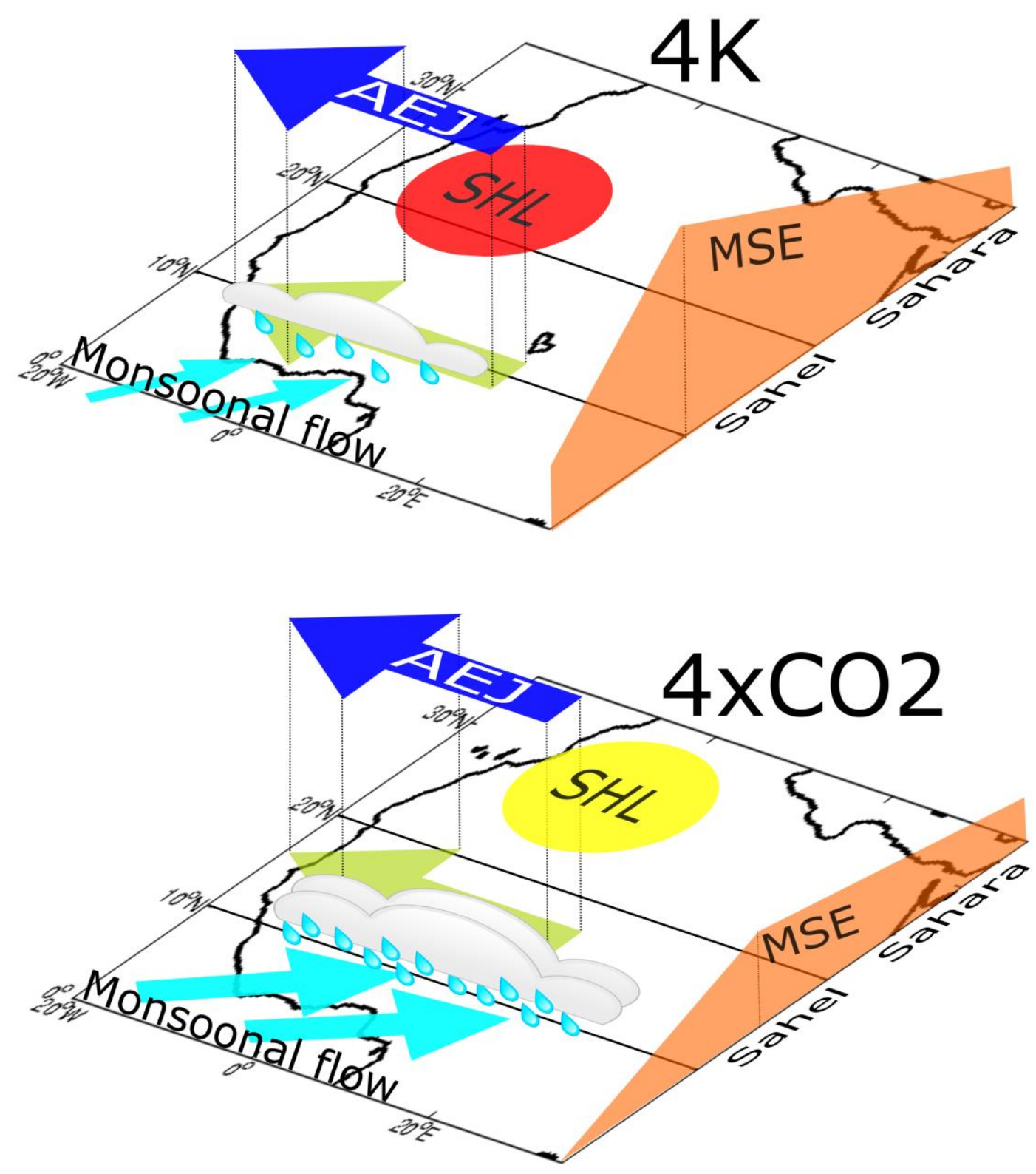

877 Figure 14: Schematics of the WAM dynamics and precipitation in the idealized simulations.

878 The displacement of the monsoonal system in the meridional direction is illustrated, along

879 with the changes in MSE content, monsoonal flow strength, and precipitation amount. A 880 stronger SHL in the $4 \mathrm{~K}$ experiment is highlighted in red. 